\title{
LAS ORACIONES INTERROGATIVAS INDIRECTAS EN LA LENGUA CULTA HABLADA EN MADRID
}

\author{
José Luis Girón AlCONChel \\ Universidad Complutense
}

\section{INTRODUCCIÓN}

1. Proposiciones «interrogativas indirectas» e «interrogativas modales». Descripción paradigmática

En un trabajo reciente y todavia inédito sobre las llamadas «oraciones interrogativas indirectas» en español medieval ${ }^{1}$ ha propuesto la distinción paradigmática de dos clases: las proposiciones interrogativas indirectas y las proposiciones interrogativas modales.

Unas y otras son:

a) proposiciones sustantivas; $y$

b) están encabezadas por una palabra interrogativa (adjetivo, pronombre $o$ adverbio interrogativos en las parciales y conjunción interrogativa si en las totales).

Pero hay un tercer rasgo distintivo, en virtud del cual se oponen las interrogativas indirectas y las modales: las primeras dependen de preguntar (y sinónimos), mientras que el verbo, locución verbal o cualquier otra clase de palabra (sustantivo, adjetivo, preposición) de que dependen las segundas no constituyen un rasgo distintivo de su definición paradigmática.

' Me refiero al libro Las oraciones interrogativas indirectas en español medieval, Madrid, Gredos, 1988, publicado cuando todavía este artículo esperaba ver la luz. 
Esta distinción en el plano de la expresión tiene su correlato en el plano del contenido: las interrogativas indirectas significan la modalidad interrogativa de la enunciación; las interrogativas modales expresan la modalidad del enunciado. Las distinción de estas dos clases de modalidad ha sido planteada por la lingüística de la enunciación, y resulta fundamental para definir paradigmáticamente la proposición interrogativa indirecta y modal. En algunos estudios recientes se ha apuntado que las diferencias observadas entre las dos clases de proposiciones interrogativas, por una parte, $y$, por otra, entre esas dos clases y las proposiciones sustantivas enunciativas o declarativas eran de indole sintáctico-semántica. En efecto, lo son. Y creo que esa doble noción de modalidad contribuye decisivamente a establecer y delimitar tales diferencias ${ }^{2}$.

La modalidad interrogativa de la enunciación es, como se sabe, una de las modalidades oracionales, expresada en las "oraciones interrogativas directas" por medio del morfema de entonación y, en las proposiciones interrogativas indirectas, por el verbo preguntar (y sus sinónimos), que, como verbo performativo, manifiesta la "fuerza ilocutiva» de la enunciación (lo mismo que la entonación) $)^{3}$.

La modalidad del enunciado es otra cosa. Se trata, desde luego, de una noción que está necesitada de un mayor desarrollo teórico; pero podemos definirla como la evaluación, por parte del hablante, de su propio enunciado. Tal evaluación puede ser lógica o apreciativa; en el primer caso, el hablante evalúa su enunciado situándolo en relación con diversas categorías lógicas (como «lo verdadero", «lo falso", «lo conocido", «lo desconocido", «lo problemático», etc.); en el segundo caso, la evaluación del enunciado se realiza por relación a diversos juicios de valor («lo feliz», «lo triste», «lo útil», «lo sorprendente», etc.).

2 A. Bello sugirió la diferencia que propongo entre interrogativas indirectas y modales, al sostener que la interrogativa indirecta "significa la cosa no sabida, preguntada o ignorada" (Gramática de la lengua castellana, anotada por R. J. Cuervo, Buenos Aires 1973, 9." ed., p. 132). Nótese la diferencia entre "cosa preguntada" (interrogativa indirecta) y "cosa no sabida - ignorada" (interrogativa modal). De un modo explícito reconocen esta diferencia -aunque sin proponer términos que eviten el equívoco-J. Alcina y J. M. BLECUA, y, además, acuden a las nociones de modus y dictum, sobre todo, para explicar las interrogativas indirectas que no significan pregunta (Gramática española. Barcelona 1975, pp. 1126-1130). Subrayan el acierto de la distinción de estos últimos autores 1 . BosQUE ("Sobre la interrogación indirecta", Dicenda, 1 (1982), pp. 13-34) y J. MARTínez MARIN («Semántica y sintaxis de las oraciones interrogativas indirectas del español», Philologica Hispaniensia in honorem M. Alvar, II, Madrid 1985, pp. 469-480. Para la noción de modalidad, cf. Ch. BALLY, Linguistique générale et linguistique française. Berne, $4^{\text {eme }}$ ed.; y para las nociones de modalidad de la enunciación y modalidad del enunciado, véase D. MAINGuenEAU, Introducción a los métodos del análisis del discurso, Buenos Aires 1980, pp. 126-127.

"Cf. Z. VENDLER, "Les performatifs en perspective", Langages, 17 (1970), 73-90. Han estudiado la interrogación directa como modalidad (de la enunciación) G. MOIGNET («Esquisse d'une théorie psycho-mécanique de la phrase interrogative», Langages, 3 (1966), pp. 49-66) y A. DiAZ TEJERA («La frase interrogativa como modalidad», RSEL, 3 (1973), pp. 95-116). 
Un conjunto de categorías lingüísticas, todavía mal descritas, constituye el plano de la expresión de la modalidad del enunciado. Una de esas categorías - la que ahora nos interesa - es la formada por los adjetivos, pronombres y adverbios interrogativos y por la conjunción interrogativa si; esta categoría es, como hemos indicado, el principal rasgo distintivo de las proposiciones interrogativas modales.

Por otra parte, las proposiciones sustantivas interrogativas (indirectas y modales) se oponen, en conjunto, a las proposiciones sustantivas enunciativas o declarativas por la expresión de la modalidad (de la enunciación o del enunciado). Las sustantivas enunciativas no expresan, desde un punto de vista paradigmático, ni modalidad de la enunciación ni modalidad del enunciado.

Lo que llevamos dicho puede resumirse gráficamente en el siguiente cuadro:

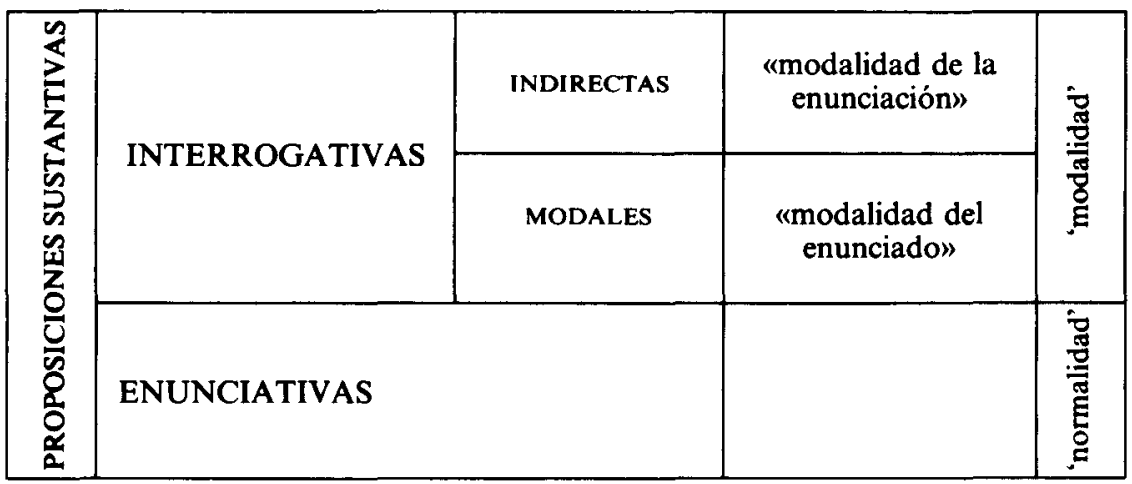

1.1. Proposiciones interrogativas indirectas en el plano sintagmático

Hasta aquí, la definición paradigmática de interrogativas indirectas e interrogativas modales. Ahora bien, en el plano sintagmático se dan casos en los que una interrogativa modal funciona como interrogativa indirecta. Compárense estos ejemplos:

a) Diré quién ha venido esta tarde. (Luego) diré si va a haber clase esta tarde.

b) Dime quién ha venido esta tarde. Dime si va a haber clase esta tarde. 
Evidentemente, en las oraciones de a) no se expresa la modalidad de la enunciación (modalidad interrogativa), sino la del enunciado; es decir, el hablante evalúa un elemento del contenido de la proposición, el sujeto en este caso (interrogativa modal parcial), o la totalidad del contenido de la proposición (interrogativa modal total), situándolo en la categoría lógica de «lo desconocido» o de «lo problemático» (no para él, sino para sus interlocutores). En cambio, en las oraciones de $b$ ) el hablante hace una pregunta a su interlocutor (parcial en el primer caso y total en el segundo): expresa la modalidad interrogativa de la enunciación. En $a$ ) tenemos, pues, dos proposiciones interrogativas modales, y en $b$ ), dos interrogativas indirectas. Pero la descripción paradigmática de unas y otras es la misma, ya que en ninguno de los dos casos decir es sinónimo de preguntar (lo que, por otra parte, ocurre en otras ocasiones, como veremos). Lo que hace que las oraciones de $b$ ) sean interrogativas indirectas es el modo imperativo del verbo decir: el imperativo significa una apelación al oyente de índole similar a la expresada por la entonación interrogativa (en las oraciones interrogativas directas) y a la expresada por el "verbo performativo" preguntar (en las proposiciones interrogativas indirectas). Pero en la definición paradigmática de una estructura oracional compleja no cabe contemplar el modo del verbo de la oración principal. Por eso designamos a las proposiciones de $b$ ) y similares con el nombre de interrogativas indirectas en el plano sintagmático. Las estudiaremos dentro de las interrogativas indirectas, pues se trata de un esquema sintagmático muy frecuente, cuyo significado es independiente de los diversos contextos lingǘsticos y, además, documentado en nuestra lengua desde los primeros textos.

Como veremos (cf. III.2.3.1.), en el habla culta de Madrid se registra también la «exclamativa indirecta en el plano sintagmático», cuyo comportamiento sintáctico es igual al de estas interrogativas indirectas, sólo que, en vez de dime, aparecen fijate o mira como imperativos que introducen la proposición, la cual significa, lógicamente, «modalidad exclamativa de la enunciación».

\section{2. "Categoria idiomática» y "categoría textual». La "pregunta» como "categoría textual»}

No hay que confundir las interrogativas indirectas en el plano sintagmático con algunas interrogativas modales (por ejemplo, las que se ajustan al esquema NO SABER + A, siendo A siempre la proposición interrogativa, cf. III.2.1.1.) que, en determinados contextos y situaciones, pueden significar 'pregunta'. Por ejemplo, en nuestro corpus del habla de Madrid encontramos el siguiente fragmento de diálogo entre dos informantes: 
Inf. A.-Estuvimos, estuvimos en el pueblo de Lozoya, no sé si lo conoces.

Inf. B.-Sí, sí, lo conozco también (350) ${ }^{4}$.

Es evidente que aquí la interrogativa modal no sé si lo conoces ha servido para formular una pregunta. Por lo menos, así lo entiende el interlocutor, y por eso la contesta. ¿Podríamos decir que se trata de una interrogativa indirecta en el plano sintagmático? No. De hecho, en otros contextos el mismo esquema, la misma interrogativa modal, sirve, no para preguntar, sino para contestar una pregunta:

Inf. B.-iCómo se llama?

Inf. A.-Mira, si quieres que te diga la verdad, ni lo sé. No sé cómo se llama... (417).

Hechos como éstos son la causa de que haya tanta confusión en las explicaciones gramaticales de estas proposiciones, $\mathrm{e}$ incluso en algunos estudios monográficos. Para salir del atolladero es necesario tener en cuenta cierta distinción sobre la que ha llamado la atención E. Coseriu: la distinción entre "categoría idiomática» y "categoría textual»s. Resumiendo, podemos decir que la categoria idiomática es un hecho de lengua, de realidad paradigmática; en cambio, la categoría textual es un hecho de discurso. Según el mismo Coseriu, la "pregunta" es una categoría textual y no una categoría idiomática: de hecho, ni siquiera las oraciones interrogativas directas se usan siempre para preguntar (por ejemplo, ¿Quién lo sabe? puede no ser una "pregunta») y, en cambio, en muchas ocasiones la "pregunta" se puede formular con construcciones que nada tienen que ver con las interrogativas.

Lo que es una "categoría idiomática» es el interrogativo; y por eso lo is también la proposición interrogativa indirecta y la proposición interrogativa modal, con independencia de que la modalidad interrogativa de la enunciación, expresada por la primera, y la modalidad lógica o apreciativa del enunciado, expresada por la segunda, puedan o no emplearse en contextos determinados para formular una "pregunta".

En este trabajo me propongo analizar las proposiciones interrogativas indirectas y modales como "categorías idiomáticas" y no como "categorías textuales». Por eso no voy a atender, sistemáticamente, a hechos como los ejemplificados en este epígrafe. Considero suficiente, desde el punto de vista de nuestro actual propósito, la explicación aquí consignada.

- M. Esgueva y M. Cantarero (eds.), El habla de la ciudad de Madrid. Materiales para su estudio (prólogo de A. Quilis), Madrid 1981. En adelante téngase en cuenta que el número que aparecerá siempre entre paréntesis, tras los ejemplos, es el de la página de esta obra.

" "La "situación" en la lingüistica», en El hombre y su lenguaje. Estudios de teoria y metodología lingüistica, Madrid 1977, pp. 240-256: 246-47.

- Cf. L. Contreras, «Oraciones interrogativas con sii, BFUCh, IX (1956-1957), pp. 67-86. 
He aqui otro asunto estrechamente vinculado a la explicación de las proposiciones interrogativas; $\mathrm{y}$, también, fuente de alguna que otra confusión. Es verdad que desde la Edad Media determinadas oraciones de relativo invaden el campo de las proposiciones interrogativas indirectas y modales. En realidad, esto ya sucedía en latín, y el origen de que este hecho se haya incrementado en las lenguas románicas y, concretamente, en español se encuentra en el mismo latín-vulgar y en los procesos de cambio protorrománicos y románicos que tienden a acercar considerablemente las esferas pronominales del interrogativo y del relativo? ${ }^{7}$ Pero, al menos en español, interrogativos y relativos constituyen "categorías idiomáticas» distintas, aunque bastante próximas: se diferencian únicamente por rasgos prosódicos (acento, entonación), pero se diferencian. Por ello no procede identificar paradigmáticamente oraciones de relativo y proposiciones interrogativas. Otra cosa es que se dé entre unas y otras, y en determinados contextos, una equivalencia sintagmática.

Estudiaremos esta equivalencia en nuestro corpus, por la antigüedad del fenómeno, por su continuidad en la lengua de hoy y, en fin, por sus mismas implicaciones teóricas.

\section{Objetivos de este estudio}

Expuestas muy sintéticamente las bases teóricas de nuestro trabajo, en lo que sigue voy a tratar de comprobar la existencia, conformación y funcionamiento de las interrogativas indirectas y de las interrogativas modales en el español culto que se habla en Madrid. Mi propósito es doble: por una parte, corroborar (y, en su caso, rectificar), en la lengua hablada de hoy, lo

7 Cf. M. Bassols de Climent, Sintaxis latina, II, Madrid 1963, p. 173; A. Ernout y F.

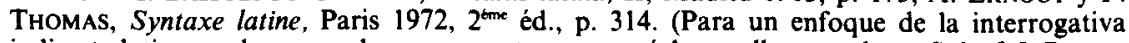
indirecta latina en el que se subrayan aspectos que aquí desarrollo para el español, cf. L RUBIO, Introducción a la sintaxis estructural del latín, II. La oración, Barcelona-Caracas-México 1976.) Sobre el acercamiento del interrogativo y del relativo en las lenguas romances, véanse E. BouR-

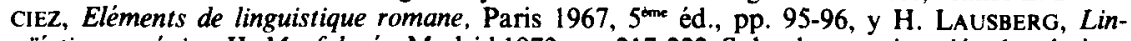
güistica románica, II, Morfología, Madrid 1973, pp. 217-222. Sobre la aproximación de relativas e interrogativas en español, cf. S. FERnANDEZ RAMírez, Gramática española. Los sonidos, el nombre y el pronombre, Madrid 1951; para S. SKYDSGAARD, por ejemplo, las interrogativas indirectas parciales son un tipo de oraciones de relativo (La combinatoria sintáctica del infinitivo español, Madrid 1977, 2 vols., pp. 1075-76); pero ya L. SPITZER subrayó la peculiaridad del interrogativo («Interrogativo e indefinido», RFH, 1 (1941), pp. 1-8). 
ya verificado en el español medieval, según dije al principio; por otra, contribuir al estudio general de la norma culta de la lengua hablada en Madrid, señalando la frecuencia y distribución de los diversos esquemas de las proposiciones interrogativas según el sexo y la edad de los informantes y según el tipo de encuesta que se ha utilizado en la recogida de datos.

$\mathrm{Ni}$ que decir tiene que la indole de este trabajo es esencialmente empirica, en los dos aspectos de su propósito; y que los resultados y conclusiones a que podamos llegar han de entenderse con exclusiva referencia a la muestra analizada. En este sentido, tales resultados no pueden calificarse sino de provisionales.

3. Esquemas oracionales de las proposiciones interrogativas de la lengua culta hablada en Madrid

Hemos encontrado los siguientes, que son, en líneas generales, los inventariados para el español medieval. (Recuérdese que A representa siempre a la proposición interrogativa):

a) Interrogativas indirectas:

1) PREgUNTAR (y sinónimos) + A.

2) DIME (y construcciones equivalentes) + A. («Interrogativas indirectas en el plano sintagmático»).

b) Interrogativas modales:

3) DECIR (u otro verbo de 'comunicación') + A.

4) SABER, VER (u otro verbo de 'entendimiento y percepción') + A. Dentro de este esquema se registra la variante: FIJATE $+\mathbf{A}$ («exclamativas indirectas en el plano sintagmático»).

5) Sustantivo, adjetivo o preposición $+\mathbf{A}$.

6) NO HABER, NO TENER + A.

\section{Descripción de la muestra}

Para realizar este trabajo he despojado exhaustivamente las 24 encuestas publicadas en el libro citado en la n. 3. La muestra está constituida por 16 
«encuestas dirigidas» (D), 4 «espontáneas» o «diálogos libres» (E) y otras 4 «secretas» (S); el total de informantes es 36 , distribuidos, según el sexo, la generación a que pertenecen y el estilo o tipo de encuesta, como muestra el siguiente cuadro ${ }^{8}$ :

\begin{tabular}{|l|c|cc|cccc|}
\hline & & \multicolumn{2}{|c|}{ Sexo } & \multicolumn{4}{|c|}{ Generaciones } \\
\cline { 3 - 7 } $\begin{array}{c}\text { Tipo de } \\
\text { Encuesta }\end{array}$ & $\begin{array}{c}\text { Número de } \\
\text { informantes }\end{array}$ & $\mathrm{V}$ & $\mathrm{H}$ & $1 .^{\mathrm{a}}$ & $2 .^{\mathrm{a}}$ & $3 .^{\mathrm{a}}$ & $4 .^{\mathrm{a}}$ \\
\hline $\mathrm{D}$ & 18 & 8 & 10 & 4 & 4 & 4 & 6 \\
\hline $\mathrm{E}$ & 8 & 3 & 5 & 7 & 1 & - & - \\
\hline $\mathrm{S}$ & 10 & 2 & 8 & 10 & - & - & - \\
\hline TOTAL & 36 & 13 & 23 & 21 & 5 & 4 & 6 \\
\hline
\end{tabular}

\section{PPROPOSICIONES INTERROGATIVAS INDIRECTAS}

\section{Dependientes del verbo PREGUNTAR y del sustantivo PREGUNTA}

La proposición sigue inmediatamente a preguntar y es objeto directo; los casos que hallo son de interrogativas parciales:

${ }^{8}$ Véase el prólogo de A. QuiLıs a El habla de la ciudad de Madrid para una información general sobre la metodología y los térmínos específicos empleados en el estudio de la lengua culta hablada en Madrid; véase también, del mismo autor, La concordancia gramatical en la lengua española hablada en Madrid, Madrid 1983. Recordamos únicamente que: "Nuestra primera generación comprende entre los quince y los veinticuatro años; la segunda generación entre los veinticinco y los treinta y cinco años; la tercera generación entre los treinta y seis y los cincuenta y cinco años, y la cuarta generación desde los cincuenta y seis en adelante» ( $E l$ habla de la ciudad de Madrid, p. XIII, n. 2). 
«me van a empezar a preguntar cómo se dice caballo y... pollo» (448).

«Te pregunto qué vas a hacer esta tarde» (401).

«hay una cola de niños para preguntar qué libro pueden leer» (338).

Entre el verbo y la proposición se intercala algún otro enunciado o fragmento de enunciado. Esto obedece a características propias del habla coloquial (elementos expresivos que interrumpen la secuencia lógica del enunciado, elaboración instantánea del pensamiento que se pretende comunicar, etc.). Encuentro sólo dos casos. Al distanciarse la proposición del verbo al que complementa, parece que aquélla se independiza y cobra aspecto de oración interrogativa directa; de hecho, en los dos casos los editores ponen signos de interrogación a la proposición subordinada. Pero no cabe dudar del carácter de interrogativa indirecta en un caso como éste:

«me debías haber preguntado ¡qué va! ¿por qué yo viajaba al extranjero?» (82).

De haber sido una interrogativa directa ( $y$, por tanto, construccion de discurso directo en este caso), la sintaxis habría obligado a la no transposición del pronombre y acaso del tiempo verbal: ¿por qué viajas (o viajabas) al extranjero?

En el segundo caso, sin embargo, la ambigüedad es mayor, ya que no se pueden realizar tales transposiciones pronominales y verbales:

«No sé, yo te preguntaría ¿eh?..., no sé... por ejemplo, ¿cuál es la última novela que tú has leído» (291).

1.1. Que enunciativo precediendo a la interrogativa indirecta

La conjunción que refuerza la construcción de discurso indirecto, al tiempo que señala la tendencia del español, desde la Edad Media, a identificar 
las proposiciones interrogativas con las otras sustantivas ${ }^{9}$. Gili Gaya opina que esta construcción es característica del habla popular corriente ${ }^{10}$; pero la he encontrado en la lengua medieval (a partir de 1200) y, ahora, en el habla culta de Madrid. Cuento cuatro casos, uno de interrogativa parcial y tres de total:

"nos ha preguntado a nosotros de balcón a balcón que qué pasaba» (370).

"yo ya pregunté que si lo estaban haciendo a letra por día» (321).

\subsection{Interrogativas indirectas dependientes del sustantivo PREGUNTA}

Encuentro un solo caso claro de subordinación: la interrogativa es sujeto, y se construye también con que enunciativo:

«Una de las preguntas era que...V... qué océano bordea las costas de América del Sur» (304).

\subsection{Casos ambiguos}

Encuentro dos casos, con el sustantivo pregunta y con la locución hacer la pregunta. Pueden interpretarse como interre:.ltivas directas; y así lo hacen los editores, que ponen signos de interrogacion:

«Esa es la pregunta tan típica de ¿tú has tenido novio?» (142-143).

${ }^{4} \mathrm{Cf}$. W. MeYer-LUbke, Grammaire des langues romanes, New York 1923 (4 vols.). vol. III, p. 652; R. J. CuERVo, Diccionario de construcción y régimen de la lengua castellana, Bogotá 1953-1954 y ss., s.v. decir; H. Keniston, The Syntax of Castilian Prose. The sixteenth Century. Chicago-Illinois 1937, pp. 675-676. Cf. también S. PLANN, «Indirect questions in Spanish», Linguistie Inquiry, 13 (1982), pp. 297-312, para quien la construcción con que enunciativo es posible sólo tras verbos de comunicación que rigen discurso directo.

${ }^{10}$ Curso superior de sintaxis española. Barcelona 1969, 9." ed., pp. 293-94. 
«usted me ha hecho la pregunta ¿qué es lo que cuesta más trabajo?» (218).

Nótese en el primer ejemplo la presencia de la preposición de, índice de subordinación sustantiva, en estos casos, y, a continuación, la sintaxis propia de la interrogativa directa, sin la conjunción subordinante si de la interrogativa total.

En estos casos, quizás lo más probable sea que la parataxis (interrogativa directa) y la hipotaxis (interrogativa indirecta) se interfieran en la construcción oral del enunciado, dando así lugar a estructuras mixtas que pueden interpretarse de una u otra forma.

1.4. Distribución de las interrogativas indirectas dependientes de PREGUNTAR y PREGUNTA

Son en total, 13 casos, que se distribuyen así:

\begin{tabular}{|c|c|c|c|c|c|c|c|}
\hline \multirow{2}{*}{$\begin{array}{l}\text { Tipo de } \\
\text { Encuesta }\end{array}$} & \multicolumn{2}{|c|}{ Sexo } & \multicolumn{4}{|c|}{ Generaciones } & \multirow{2}{*}{ Total } \\
\hline & $\mathrm{V}$ & $\mathbf{H}$ & 1." & $2 .^{\circ}$ & 3." & 4. & \\
\hline D & 2 & 3 & 1 & 1 & 1 & 2 & 5 \\
\hline $\mathrm{E}$ & 3 & 3 & 5 & 1 & - & - & 6 \\
\hline$S$ & - & 2 & 2 & - & - & - & 2 \\
\hline TOTAL & 5 & 8 & 8 & 2 & 1 & 2 & 13 \\
\hline
\end{tabular}


1.5. Oración de relativo con valor de interrogativa indirecta dependiente de PREGUNTAR

Hay un solo caso en todo nuestro corpus; pertenece a un varón de la tercera generación en «diálogo dirigido»:

«yo pregunté... en fin, lo que ganaban» (161).

\section{Interrogativas indirectas dependiente de DECIR y de PENSAR}

Decir, con el significado de «preguntar», introduce la interrogativa indirecta parcial y se construye con el que enunciativo en cuatro casos. No encuentro ejemplos de interrogativas totales:

«A. dijo que por qué no íbamos a cenar por ahí» (114).

«nos llama desde Caracas ni yerno, el padre del chico, diciendo que qué es eso que cómo no había ido su hijo» (236).

En una ocasión decir, sin que, introduce la interrogativa indirecta total, y toda la oración compleja es, a su vez, una interrogativa directa:

«idices si estoy contenta?» (84).

En dos casos decir que introduce, no una interrogativa indirecta, sino una exclamativa indirecta; es decir, la proposición subordinada expresa la modalidad exclamativa de la enunciación. Se comprueba en estos casos que la "pregunta» no es una categoría idiomática, sino una categoría textual y que los interrogativos y la proposición interrogativa indirecta (que sí son categoría idiomáticas) se pueden emplear para otra cosa que preguntar (cf. I.1.2.): 
«mi padre dijo que para qué iba a esperar» (11).

«Oye, pero yo digo que qué cosas más raras» (412).

Con pensar (= «preguntar» o «preguntarse») encuentro sólo dos casos con interrogativas parciales:

«Para que no tenga que casarse pensando quién la va a mantener» (68).

«estoy pensando yo ahora dónde aprobé yo sexto, la reválidad de sexto, que no me acuerdo» (322).

La distribución de la interrogativa indirecta dependiente de decir y pensar es ésta:

\begin{tabular}{|l|cc|cccc|c|}
\hline \multirow{2}{*}{$\begin{array}{l}\text { Tipo de } \\
\text { Encuesta }\end{array}$} & \multicolumn{2}{|c|}{ Sexo } & \multicolumn{3}{|c|}{ Generaciones } & \multirow{2}{*}{ Total } \\
\cline { 2 - 6 } & V & H & $1 .^{*}$ & $2 .^{*}$ & $3 .^{*}$ & $4 .^{\mathrm{a}}$ & \\
\hline D & 3 & 4 & 3 & 2 & - & 2 & 7 \\
\hline E & - & 1 & - & 1 & - & - & 1 \\
\hline S & - & 1 & 1 & - & - & - & 1 \\
\hline TOTAL & 3 & 6 & 4 & 3 & - & 2 & 9 \\
\hline
\end{tabular}

\section{Interrogativas indirectas en el plano sintagmático}

Son las que se encuadran en el esquema general DIME (y construcciones equivalentes) + A (cf. I.1.1. y I.3.). Encuentro cuatro casos (todos de in- 
terrogativas parciales), uno con dime y los otros con las variantes ya me dirás tú, explícame y oiga:

«dime, qué te pasa» (365).

"ya me dirás tú qué temas sacamos ahora» (341).

«Explícame cómo, cómo funciona» (315).

«pero ¿oiga que usted qué está haciendo ahí? (303).

Como ya observó Bello, algunas de estas construcciones pueden interpretarse como interrogativas directas o como interrogativas indirectas, según haya o no pausa significativa entre el imperativo y el interrogativo". Así, el primero de los ejemplos sería ambiguo. Muestra esto, una vez más, la contienda que se establece entre parataxis e hipotaxis en la lengua del coloquio, incluso entre interlocutores cultos. El último ejemplo es también significativo al respecto: los editores ponen signos de interrogación (interrogativa directa), pero, al mismo tiempo, aparece un que; puede interpretarse como el que enunciativo de algunas interrogativas indirectas o como un elemento de la función fática, de tanto rendimiento en la lengua hablada. En cualquier caso, la ambigüedad persiste. $Y$ ello quiere decir, entre otras cosas, que los elementos suprasegmentales (entonación, acento) no son por completo ajenos a la explicación gramatical de las interrogativas indirectas.

La distribución de estos casos es la siguiente:

"Gramática..., p. 372. 


\begin{tabular}{|c|c|c|c|c|c|c|c|}
\hline \multirow{2}{*}{$\begin{array}{l}\text { Tipo de } \\
\text { Encuesta }\end{array}$} & \multicolumn{2}{|c|}{ Sexo } & \multicolumn{4}{|c|}{ Generaciones } & \multirow{2}{*}{ Total } \\
\hline & $\mathrm{v}$ & $\mathrm{H}$ & 1. & 2." & 3." & 4. & \\
\hline $\mathrm{D}$ & - & - & - & - & - & - & - \\
\hline $\mathrm{E}$ & 2 & 2 & 4 & - & - & - & 4 \\
\hline S & - & - & - & - & - & - & - \\
\hline TOTAL & 2 & 2 & 4 & - & - & - & 4 \\
\hline
\end{tabular}

\section{4. «Pregunta indirecta libre» en la lengua hablada}

La "pregunta indirecta libre» no es, en sentido estricto, una proposición interrogativa indirecta, sino un caso concreto de discurso indirecto libre. Su estudio compete, pues, no al ámbito de la oración gramatical como «categoría idiomática», sino al de la construcción del discurso reproducido como "categoría textual». Esta construcción conserva la entonación y el orden de palabras característicos de la oración interrogativa directa (por ejemplo, la inversión del sujeto), pero, al mismo tiempo, sufre la transposición de las formas verbales y deícticas, como el discurso indirecto y el indirecto libre. Se trata de un procedimiento eminentemente literario, documentado en nuestra lengua desde antiguo ${ }^{12}$. Pero, en una ocasión, aparece en el habla de Madrid, en boca de un varón menor de 25 años (primera generación), en una «encuesta espontánea» $(E)$.

12 Fabló con los de Castejón, y envió a Fita y a Guadalfajara,/esta quinta por quanto serié conprada, Mio Cid, vv. 518-519; estando en el hogar solo un tizo, me quiso aporrear: que por qué gastaba tanta leña, M. ALEMÁN, Guzmán de Alfarache, II, 64, 10 (ejemplo de H. KENISTON, The Syntax..., pp. 675-676). Cf. M. LIPS, Le style indirect libre, Paris 1926, cap. VI; $O$. JESPERSEN, La filosofia de la gramática, Barcelona 1975, p. 360; G. VERDín DIAZ, Introducción al estilo indirecto libre en español, Madrid 1970, pp. 91-92. [Véase ahora J. L. Giron AlConCHEL, Las formas del discurso referido en el «Cantar de Mio Cid», Madrid, Real Academia Española, 1989 (Anejo XLIV del $B R A E$ ).] 
«El otro... ayer, hablando con un amigo, que fui... que si sería yo capaz de marcharme de aquí...» (335).

El ejemplo, por otra parte, prueba la extensión del discurso indirecto libre a la lengua no literaria, fenómeno que he estudiado en otro lugar ${ }^{13}$.

\section{Proposiciones INTERRogativas MODALES}

1. Dependientes de un verbo de «comunicación»

\subsection{Proposiciones interrogativas modales}

Responden al esquema general DECIR + A. Encuentro un total de 12 casos, siempre de interrogativas parciales. La interrogativa modal es objeto directo o complemento preposicional del verbo o locución que significa "acto de habla»: de decir (en seis casos), de hablar de (2), de explicar (2), de quejarse de (1) y de dar pelos y señales de (1):

«no dicen en qué ejército están para que no los pesquen» (54).

«No te puedo decir cómo es» (429).

«me gustaria que habláramos... de cómo está hoy la novela en lengua castellana" (291).

«pero no te puedo explicar cómo, ni qué cara tenía, ni nada» (112).

«Siempre se quejan un poco de por qué tenemos que sentir...» (96).

«se creen con el derecho de que les des... pelos y señales... de qué le ha pasado al libro" (127).

En dos casos - ambos dependientes de decir - se altera el orden de

13 "La "escritura del habla" y el discurso indirecto libre en español», $A F A, \mathrm{XXXVI-}$ XXXVII (1985), pp. 173-204: 202-204. 
palabras. En uno el sujeto de la proposición resulta atraído a la oración principal:

«no puedo decir, estos señores de mi misma edad aproximadamente, cómo piensan ante la vida» (37).

En otro el hablante emplea la construcción «lo que... es que...», idónea «para poner de relieve lo que se va a decir, y al mismo tiempo avivar la atención del interlocutor» ${ }^{14}$ :

«lo que tenian que decirnos alguno (sic), era que de una vez, qué hay o qué no hay" (52).

La distribución de este tipo de interrogativa modal se recoge en el siguiente cuadro:

\begin{tabular}{|c|c|c|c|c|c|c|c|}
\hline \multirow{2}{*}{$\begin{array}{l}\text { Tipo de } \\
\text { Encuesta }\end{array}$} & \multicolumn{2}{|c|}{ Sexo } & \multicolumn{4}{|c|}{ Generaciones } & \multirow{2}{*}{ Total } \\
\hline & V & $\mathrm{H}$ & $1 .^{\mathrm{a}}$ & $2 .{ }^{\mathrm{a}}$ & 3." & $4 .^{a}$ & \\
\hline D & 2 & 5 & 4 & 3 & - & - & 7 \\
\hline$E$ & 2 & 2 & 4 & 一 & - & - & 4 \\
\hline $\mathbf{S}$ & 一 & 1 & 1 & - & - & - & 1 \\
\hline TOTAL & 4 & 8 & 9 & 3 & - & - & 12 \\
\hline
\end{tabular}

14 W. Beinhauer, El español coloquial, Madrid 1973, 2." ed., p. 105. Nótese cómo en el ejemplo que sigue la interrogativa modal no es formalmente objeto directo de decir, aunque el hecho no invalida la generalización que hemos establecido al principio de este epigrafe. 
1.2. Oraciones de relativo con valor de interrogativas modales dependientes de un verbo de "comunicacion»

Hay únicamente tres casos; en los tres el relativo carece de antecedente y adopta la forma lo que; la oración subordinada es objeto directo:

«no te he dicho lo que parece» (337).

«Me gusta mucho decir y repetir a todas mis amistades lo que yo quiero a España» (264).

«ya me informarás mañana de lo que pasa» (441).

La distribución de estos tres casos es la siguiente:

\begin{tabular}{|c|c|c|c|c|c|c|c|}
\hline \multirow{2}{*}{$\begin{array}{l}\text { Tipo de } \\
\text { Encuesta }\end{array}$} & \multicolumn{2}{|c|}{ Sexo } & \multicolumn{4}{|c|}{ Generaciones } & \multirow{2}{*}{ Total } \\
\hline & $\mathbf{V}$ & H & $1 .^{a}$ & $2 .{ }^{\circ}$ & $3 . "$ & 4. & \\
\hline D & - & 1 & - & - & - & 1 & 1 \\
\hline$E$ & - & 1 & - & 1 & - & - & 1 \\
\hline$S$ & 1 & - & 1 & - & - & - & 1 \\
\hline TOTAL & 1 & 2 & 1 & 1 & - & 1 & 3 \\
\hline
\end{tabular}




\section{Interrogativas modales dependientes de verbos de «entendimiento y percepción»}

Se ajustan al esquema SABER, VER (u otro verbo de significado parecido) + A. Este esquema es el que más se realiza, con mucho, en la lengua hablada en Madrid. El verbo que más veces aparece es saber, seguido a mucha distancia por ver. Luego vienen, también a gran distancia, los demás verbos.

\subsection{Interrogativas modales dependientes de $S A B E R$}

Lo mismo que en la lengua medieval, y en la clásica ${ }^{15}$, saber aparece en construcción negativa, en construcción que implica negación y en construcción afirmativa. Los casos más numerosos corresponden a la primera variante y los menos a la última; en todos la interrogativa modal es objeto directo de saber.

\subsubsection{SABER en construcción negativa}

En los esquemas hasta ahora analizados el verbo de la proposición interrogativa (indirecta y modal) estaba siempre en indicativo. En NO SABER + A puede estar, además, en infinitivo y en subjuntivo; y puede también no aparecer verbo en la subordinación.

\subsubsection{NO SABER + A con el verbo de $A$ en indicativo}

Es la variante más numerosa. Encuentro un total de 120 casos: 58 de interrogativas parciales y 62 de totales. Esta proporción también singulariza a la variante que estudiamos, pues hasta ahora las interrogativas totales han sido menos frecuentes que las parciales, tanto en la interrogativa indirecta como en la modal.

Algunos ejemplos de interrogativas parciales:

«Y no sé qué estabas haciendo tú así» (411).

«no sé yo a qué hora abren» (426).

is Cf. H. Keniston, The Syntax..., p. 348 y 391-392. 
«Y yo no sé hasta qué punto se puede aprender un idioma en tres años» (393).

«no sabíamos en realidad por qué estábamos» (104).

«no sé cómo se llama» (115).

«no sé quién es ese señor» (239).

«no sabía dónde estaba» (420).

"y no sabemos realmente...V... cuáles van a ser los cambios futuros» (169).

En las interrogativas totales se observa una mayor casuística:

a) Se construye sin disyuntiva:

«no sé si te has dado cuenta» (315).

«yo no sé si eso hará gracia a los niños» (204).

b) Se construye con disyuntiva:

1) Se enuncian los dos miembros de la disyuntiva:

«no sé si empezó él o el otro» (443).

«Yo no sé si era mucho o era poco» (330).

2) Se enuncia sólo el primer miembro y la conjunción $o$ seguida de una suspensión tonal:

"Yo no sé si esto sería el Ateneo antes, o...» (409).

«Yo no sé si lo habrán abierto ya o...» (409).

3) El último miembro de la disyuntiva -que puede tener hasta 
tres- es una interrogativa modal parcial (completa o reducida al interrogativo):

«no se sabe si ha sido raptado o qué» (49).

«tampoco sé si yo tengo razón o estoy confundido o qué me ocurre» (47).

«no sé si era chico o si era chica, ni quién era» (330).

\subsection{Construcciones especiales de «NO SABER SI»}

La interrogativa modal total presenta algunas construcciones en las que vale la pena detenerse:

a) No sé si es que...

Encuentro esta construcción en tres ocasiones únicamente:

«no sé si es que estaré chiflada» (286).

«no sé si es que estaba ya cansada, con sueño» (439).

no sé si es que es al principio» (446).

Estos ejemplos corroboran, desde luego, el significado paradigmático de la interrogativa modal; en estos casos, «evaluación lógica, con respecto a lo problemático, lo ignorado, del contenido de la proposición». Ahora bien, el giro es que añade un nuevo matiz modal a ese significado. "Es que», en la lengua coloquial, se puede emplear en afirmaciones y en interrogaciones; según W. Beinhauer, sirve para introducir «la aclaración de una circunstancia que la necesita»; cuando se usa para preguntar, también posee este sentido, de modo que «iEs que está enfermo?» equivale a «Es porque está enfermo?»"16.

16 Op. cit.. p. 106. 
El hecho de que «es que» se emplee en la interrogación directa con cierta frecuencia - no siempre- puede favorecer que la construcción no sé si es que... posea, en el discurso y en determinados contextos, un sentido del «pregunta" (cf. I.1.2.).

b) ¿No sé si...?

Encuentro dos casos:

«Era R., ¿no sé si habrás oído hablar de él?» (416).

«¿no sé si la conoces?» (363).

En ambos la interrogación directa sirve para preguntar: el interlocutor contesta con un "no" en las dos ocasiones. Este «no" equivale, en el primer caso, a "no he oído hablar de él» y, en el segundo, a "no la conozco»; es decir, el contenido de la interrogación directa - aquello por lo que se pregunta- no es el de la oración principal («no sé»), sino el de la proposición subordinada. En suma, un mismo contenido experimenta una doble modalización: modalidad lógica del enunciado y modalidad interrogativa de la enunciación. Por una parte, esto es una prueba de la existencia paradigmática de las interrogativas modales: son las proposiciones interrogativas que, para que signifiquen «interrogación», han de estar caracterizadas por el morfema de la entonación interrogativa. Por otra parte, cabe plantearse qué pasa cuando en un enunciado concurren las dos modalidades interrogativas, la de la enunciación y la del enunciado. Estudiando un tipo de interrogativas directas parecidas a las nuestras - con saber sin negación: «¿Sabía yo por dónde andabais?» (J. Poncela)—, Ph. Turnbull, apoyándose en S. Fernández Ramírez, subraya el «escaso valor inquisitivo» de las mismas: la interrogativa directa sirve para hacer una "llamada de atención", más que para hacer una pregunta ${ }^{17}$. En nuestros ejemplos, la construcción negativa de saber subraya el valor expresivo - más que conativo- de la interrogación directa: el mismo S. Fernández Ramírez señaló el valor fundamentalmente expresivo de la pregunta (directa) con no. En cualquier caso

1 Ph. Turnbull, «La frase interrogativa en la poesía contemporánea (M. de Unamuno, Juan Ramón Jiménez, A. Machado, J. Guillén)», BRAE, XLIII (1963), pp. 473-605: 536 y 545; S. FernÁndeZ RAmirez, «Oraciones interrogativas españolas», $B R A E, \mathrm{XXXIX}(1959)$, pp. 243-276. 
-y dicho ya con los términos propios de la explicación que proponemos en este trabajo-, la modalidad del enunciado ("evaluación lógica») de la interrogativa modal restringe el significado de «pregunta» de la modalidad interrogativa de la enunciación de la interrogación directa y, al mismo tiempo, destaca los aspectos expresivos y conativos inherentes a dicha modalidad de la enunciación.

c) "no sé si sabes el parque que digo» (361)

$\mathrm{Si}$, como hemos visto en esquemas anteriores (cf. I.1.3., II.1.5., III.1.2.) y veremos en este mismo y en otros, la oración de relativo puede tener un valor sintagmático de proposición interrogativa -indirecta y modal-, lo que tenemos en esta construcción (caso único en nuestro corpus) es una interrogativa modal parcial (expresada en el plano sintagmático por la oración de relativo) subordinada a una proposición interrogativa modal total: desde el punto de vista del plano de la expresión, lo que a veces las gramáticas llaman una "subordinada de segundo grado". En correspondencia, desde el punto de vista del plano del contenido, observamos una doble modalidad del enunciado: se evalúa lógicamente, y al mismo tiempo, un contenido proposicional en uno de sus constituyentes (interrogativa modal parcial) y el contenido proposicional de que forma parte el primero en su totalidad (interrogativa modal total). De este modo se consigue un enunciado fuertemente modalizado, apto para manifestar, en el discurso, diversos sentidos expresivos y conativos. Por supuesto, uno de esos sentidos textuales puede ser el de "pregunta", que es lo que ocurre en nuestro ejemplo. Pero aun en este supuesto, lo que predomina son los valores expresivos. Es significativo que, en el caso que comentamos, la respuesta del interlocutor —que reproduzco íntegra - es, al mismo tiempo, sí y no: «Si, no, además por allí... por alli, ocurre una cosa y es que hay bastante espacio ino?, o sea...» (361).

\subsection{Alteraciones del orden de palabras en la variante NO SABER + A con indicativo en $\mathrm{A}$}

Se dan tanto en las interrogativas parciales como en las totales.

En las parciales sólo en una ocasión el orden alterado parece deberse al cruce de formas de realce expresivo con un pensamiento poco formalizado:

«lo que pasa que no sé en qué curso, que por lo visto había un chico sólo...» (393). 
En otros cuatro casos la alteración consiste en la atracción a la oración principal del verbo de la proposición subordinada:

«tengo no sé qué historias en el colegio que hacer» (211).

«se puso... yo no sé cuántas cosas» (347).

«Estuvieron no sé cuántas horas en el agua» (241).

«Bueno, pues he leído en no sé dónde que...» (449) ${ }^{18}$.

En las interrogativas totales la alteración del orden de palabras se debe siempre a este fenómeno; se anticipa el sujeto, el verbo, el objeto directo o los tres elementos:

«la gente no... no sé si se ha dado cuenta» (47).

«Un chico joven no sabes si es un obrero, o si es un estudiante» (254).

«un pueblecito que se llama Torreiglesias que está no sé si a cuarenta kilómetros de Segovia o asì (117).

«me puse no sé si con... en la segunda mesa, empezando por el final» (416).

«y gusto no sé si tendrán» (56).

«estos gorriones yo los he hecho no sé si en unas horas, si en unos minutos, si en una mañana» (219).

\subsubsection{NO SABER $+A$ con el verbo de $A$ en infinitivo}

Esta variante es mucho menos frecuente que la anterior: encuentro 18 casos, de los que 17 son de interrogativas parciales.

1 Nótese que en este ejemplo tambièn se anticipa la preposición en, como ocurre con según (cf. luego, III.3.). 
Para que sea posible esta construcción, que se documenta en latín y en todas las épocas del español, el infinitivo y el verbo de la oración principal han de tener el mismo sujeto.

Algunos ejemplos de interrogativas parciales:

«y ya no sé qué decirte más» (127).

«Todavía no sabes ni qué argumento... poner» (348).

«no sé cómo decir» (143).

«y no sabían dónde ir ya» (161).

El único caso de interrogativa total:

«No sé si... ofenderme o ponerme contenta» (183).

Únicamente en una ocasión encuentro alteración del orden de palabras. Sin duda, está provocada por el giro de realce expresivo «lo que... es...»:

«Hay un Morelos, pero lo que no sé es colocarlo en dónde» (444).

\subsubsection{NO SABER + A con el verbo de A en subjuntivo}

Como era de esperar, esta variante es muy poco frecuente; sólo anoto dos casos (de interrogativas parciales):

«no sé qué tanta intimidad tengan» (318).

«yo no sé, cómo siendo un paí, Sudamérica, tan rico, se tengan que ir la gente a vivir a Estados Unidos» (381).

En ninguno de los dos está exigido el subjuntivo por la proposición 
interrogativa modal, sino que, como modo verbal de la «no realidad», sirve para expresar la duda ${ }^{19}$, un significado modal que se añade a la modalidad del enunciado expresada por la interrogativa modal. El subjuntivo en ésta es siempre raro, incluso en la lengua medieval (en donde se observa que va disminuyendo de los orígenes a 1400), y mucho más raro en la lengua moderna.

\subsubsection{NO SABER+A sin verbo en $A$}

En total, cuento 25 casos de esta variante. La ausencia del verbo en la subodinada se puede deber a elipsis, a la no terminación de la frase, o bien a la lexicalización - más o menos estable- de la secuencia no saber + interrogativo.

a) La elipsis se explica fácilmente porque los elementos elididos acaban de expresarse en la oración inmediatamente anterior, o bien porque el contexto lingüístico o la situación hacen innecesaria su mención. Ocurre en interrogativas parciales y totales:

«porque todo esto lo tiene roto; no se sabe de qué» (410).

«estaba colérico y no sé por qué» (310).

«no sé qué tanto el corcho» (332).

«empezaba yo a moverme y no sé si dentro del barrio» (205).

«no sé si por mucho tiempo» (11).

«no sé si para bien o para mal» (114).

b) El dejar la frase inconclusa es un hecho habitual en el coloquio; puede estar determinado por diversos factores, en los que ahora no vamos a entrar. Sin embargo, en la variante que estudiamos sólo hallo dos casos, ambos de interrogativas totales:

19 Cf. V. PÉREZ SOler, «Construcciones con verbos de duda en español», Hispania, XLIX (1966), 287-289. 
«No sé si el presupuesto...» (332).

«no sé si así...» (12).

Y uno más, muy curioso, en que se mezclan la interrogativa total y la parcial:

«no sé si qué....» (318).

c) La lexicalización de la secuencia «no sé qué» es la más estable en la lengua general, y la más frecuente en nuestro corpus (ocho casos); no sé qué es un verdadero sustantivo, que se emplea para determinar a otro:

«una copa de no sé qué» (354).

Y que puede él mismo admitir determinaciones:

«no sé qué más» (56).

El hablante lo emplea muy a menudo cuando reproduce el discurso de otro, para concluir la reproducción (equivale, casi, a un «etcétera»):

«Y dice: ¡Ah!, ¿te vienes conmigo? y no sé qué» (347).

A «no sé qué» le sigue en frecuencia «no sé por qué» (cuatro casos); y ya se usan mucho menos «no sé cómo» (un caso) y «no sé cuánto» (otro).

2.1.2. SABER en construcción que implica negación

La negación puede estar implícita en la construcción de saber. De este tipo encuentro cuatro casos, todos de interrogativas parciales: 
«sabe' Dios dónde habrá ido a parar aquel hombre» (277).

«vete tú a saber cómo habrán sido las cosas» (50).

«... con una persona que tú sepas perfectamente cómo es ella» (144).

«... para saber por lo menos, cada tema qué libro tienes que consultar» (438).

Por otra parte, la negación está implícita en la interrogativa directa (de la que depende la interrogativa modal): si se pregunta si se sabe algo, es que se presupone que se puede no saber. De este tipo hay cinco casos (tres de interrogativas parciales y dos de totales):

«¿sabes quién la utiliza más?» (347).

«isabes si hay algún servicio por aqui?» (420).

Para el escaso «valor inquisitivo» de estas «preguntas», vale lo dicho en 2.1.1.1.1.b).

2.1.3. SABER en construcción afirmativa

Encuentro 10 casos, de los que nueve son de interrogativas parciales:

«iAh!, pues ya sé cuál es» (320).

«además usted sabe qué ingrato es el dichoso piano» (208).

«ile encantaba ver a la gente! saber cómo eran unos y otros» (269).

Como se puede observar, el significado de la interrogativa modal no es «evaluación lógica» del enunciado, sino, «evaluación apreciativa»: lo que algunos llaman "exclamativas indirectas". Pero este valor exclamativo es una 
"categoria textual», no una "categoria idiomática»: el que saber esté en construcción afirmativa es un factor para crear el sentido exclamativo, pero no un factor decisivo. Interviene también la indole semántica de la palabra interrogativa. Algunas - cuál, cuánto, cómo- favorecen grandemente la expresión de la "evaluación apreciativa»; otras, como el adverbio qué («qué ingrato»), poseen exclusivamente ese significado: ¡Qué sólos se quedan los muertos!, pero * ¿qué solos se quedan los muertos? ${ }^{20}$ En cualquier caso, el sentido exclamativo depende también de otros factores (entonación exclamativa, interjecciones, etc.), como vemos en los ejemplos consignados.

Que saber afirmativo no basta para que la proposición posea el significado de "evaluación apreciativa» se comprueba en el siguiente caso (en el que, además, se observa la típica alteración del orden de palabras por atracción de elementos de la subordinada a la principal):

«o sea que... saber..., por ejemplo el Valle del Duero, con quién se repobló..., se repobló, con qué provincias, con qué señores..., jen fin!, no importa nada para pasar al Feudalismo» (431-432).

La interrogativa modal total expresa, en cambio, «evaluación lógica» del enunciado:

«viendo los milibares yo sé si hay borrascas o hay tal...» (304).

${ }^{20}$ Cf. R. García RIVERón, "La actualización de la incógnita en las interrogativas rusas y españolas», RSEL, 15 (1985), pp. 321-342; I. BosQUE, art. cit., pp. 23-31. 
2.1.4. Distribución de la proposición interrogativa modal dependiente de SABER

\begin{tabular}{|c|c|c|c|c|c|c|c|}
\hline \multirow{2}{*}{$\begin{array}{l}\text { Tipo de } \\
\text { Encuesta }\end{array}$} & \multicolumn{2}{|c|}{ Sexo } & \multicolumn{4}{|c|}{ Generaciones } & \multirow{2}{*}{ Total } \\
\hline & V & $\mathrm{H}$ & 1." & $2 .^{a}$ & $3 .{ }^{a}$ & 4." & \\
\hline D & 22 & 72 & 30 & 25 & 18 & 21 & 94 \\
\hline $\mathbf{E}$ & 13 & 38 & 41 & 10 & - & - & 51 \\
\hline $\mathbf{S}$ & - & 39 & 39 & - & - & - & 39 \\
\hline TOTAL & 35 & 149 & 110 & 35 & 18 & 21 & 184 \\
\hline
\end{tabular}

2.1.5. Oraciones de relativo con valor de interrogativas modales dependientes de SABER

Encuentro 31 casos: 27 de oraciones de relativo sin antecedente (siempre con «lo que»), y 4 con antecedente. La oración de relativo ocupa las mismas variantes que la interrogativa modal:

a) NO SABER (14 casos).

«yo no sé lo que hago» (362).

«el español no sabe lo que lee muchas veces» (294).

En ocasiones, el orden de palabras sufre una ligerísima alteración, bien porque se emplea una fórmula de realce expresivo, bien porque entre el verbo principal y la oración de relativo se intercala una oración parentética:

«lo que no sé es lo que buscáis» (183).

«no sabemos, ese es nuestro gran problema, lo que hará» (125). 
En un par de ocasiones toda la oración se pronuncia con entonación interrogativa:

«iA que no sabemos lo que he hecho esta noche? (338).

Y en tres casos aparece la oración de relativo con antecedente:

«y no sé el valor que podrá... tener» (295).

"yo no sé las dificultades que habrá» (381).

«tú no sabes el corte que es pasarse una tarde así...» (410).

b) SABER en construcción que implica negación (15 casos, de los que 13 son de interrogativas directas):

«tienes que saber lo que es una jarcha» (298).

«iSabes lo que estoy pensando? (418).

«Sabes lo que pasa?» (415).

En un caso el orden de palabras se altera por anticipación de un elemento de la oración subordinada:

«¿Otro examen, sabes lo que pasó otro examen de Preu? (330).

c) SABER afirmativo (dos casos):

"Yo ya sé lo que quiere que digas» (442)

«Ya sabe usted lo que pasa en estas cosas» (207) 
La distribución de las oraciones de relativo es la siguiente:

\begin{tabular}{|c|c|c|c|c|c|c|c|}
\hline \multirow{2}{*}{$\begin{array}{l}\text { Tipo de } \\
\text { Encuesta }\end{array}$} & \multicolumn{2}{|c|}{ Sexo } & \multicolumn{4}{|c|}{ Generaciones } & \multirow{2}{*}{ Total } \\
\hline & V & $\mathbf{H}$ & 1. ${ }^{\mathrm{a}}$ & 2." & 3." & 4. & \\
\hline D & 2 & 6 & - & 3 & 2 & 3 & 8 \\
\hline E & 4 & 11 & 12 & 3 & - & - & 15 \\
\hline $\mathbf{S}$ & - & 8 & 8 & - & - & - & 8 \\
\hline TOTAL & 6 & 25 & 20 & 6 & 2 & 3 & 31 \\
\hline
\end{tabular}

2.2. Proposiciones interrogativas modales dependientes de VER

De acuerdo con la construcción de ver, aparecen las siguientes variantes, ordenadas de mayor a menor según la frecuencia de cada una:

1) A VER (en construcción independiente) + A.

2) VER, VIENDO (núcleos de una proposición subordinada) + A.

3) Perífrasis aspectuales o modales con VER + A.

4) VER en forma personal + A.

Todas estas variantes rigen interrogativas parciales y totales; $y$, en todas, la interrogativa modal es objeto directo de ver. 
2.2.1. A VER (en construcción independiente) + A

Es la variante más frecuente, con 29 casos ( 12 de interrogativas parciales y 17 de totales):

«a ver qué pasa» (199).

«a ver quién llegaba primero» (354).

«a ver cuándo se dan cuenta» (312).

"A ver si estás confundida" (337).

«A ver si por lo menos nos aprueban» (408).

En una ocasión aparece el giro de realce expresivo «es que» en la subordinada (cf. 2.1.1.1.1.a).):

«A ver si es que no es cierto» (394).

Y, en otra, toda la frase adopta la modalidad exclamativa:

«A ver si nos concentramos!» (400).

En tres casos, además, la interroativa modal total no llega a enunciarse, y queda sugerida por la conjunción si:

«A ver si..." (334 y 449)

«A ver si... pero no hay manera» (192).

Esto aparte, encuentro dos casos en que se emplea a ver, no para introducir una interrogativa modal, sino para llamar la atención sobre una interrogativa directa (parcial):

«A ver, ¿qué otro tema?» (383).

«A ver, ¿cuándo terminas?» (440). 
Hay que poner en relación estos ejemplos con otros de la misma índole ya analizados (cf. II.1.3. y II.3.). Desde un punto de vista teórico son muy interesantes. En primer lugar, ponen de manifiesto el origen paratáctico de las proposiciones interrogativas indirectas y modales ${ }^{21}$. En segundo lugar, hablan muy convincentemente de la pertinencia sintáctica y semántica de los elementos suprasegmentales (pausa y entonación, sobre todo). En efecto, si eliminamos la pausa entre "a ver" y el interrogativo y cambiamos la entonación interrogativa por la enunciativa, obtenemos secuencias del tipo A ver qué otro tema, A ver cuándo terminas, del todo idénticas a las estudiadas en este mismo epígrafe. Y, sin embargo, lo que con ellas se diría sería otra cosa: al pronunciar "A ver, ¿cuándo terminas?», el hablante establece una relación interpersonal, social, en la que es imprescindible la presencia de un interlocutor, sea real, o ficticio en el caso del monólogo (modalidad de la enunciación) ${ }^{22}$; por el contrario, al decir "A ver cuándo terminas», el hablante se limita a considerar «problemático» - «desconocido», «incierto», "probable» o «improbable», etc.- el momento en que aquél a quien habla va a terminar (modalidad del enunciado).

Como hemos visto, en la lengua hablada, incluso en la culta, las interferencias de parataxis e hipotaxis son más frecuentes que en la lengua escrita; y pueden dar lugar a enunciados ambiguos.

\subsubsection{VER, VIENDO (núcleos de una proposición subordinada) $+\mathrm{A}$}

Encuentro 18 casos de esta variante de compleja casuística:

a) VER, precedido de a o para, constituye una proposición subordinada final, de la que depende la interrogativa modal; en esta construcción es más frecuente A VER + A (ocho casos) que PARA VER + A (4). Veamos algunos ejemplos de parciales y totales:

«Otra que viene a ver qué pasa» (193).

«... haberme parado trescientas veces a ver cómo vive un gorrión» (219).

${ }^{21}$ Cf. M. Bassols, op. cit., p. 170. En español medieval hay ejemplos, como el siguiente, que muestran ese origen paratáctico: “¿Quál es vuestra venida? Yo saberlo querria, BERCEO, Sta. Or., 166 (ejemplo de Cuervo).

${ }_{22}$ Cf. D. Maingueneau, op. cit., p. 126. 
«he... echado agua para ver cómo era la herida» (133).

«fui a hacerme un test... a ver si era tonta» (326).

«para ver si estás aferrado a ella con miedo» (9).

En una ocasión la informante vacila: inicia una interrogativa total y, tras suspensión, enuncia una parcial:

«me fui a casa de una amiga... a ver si... a ver qué vestido se iba a poner para mi boda» (112).

b) HASTA VER (subordinada temporal) + A. Registro un solo caso:

«nos recluimos en nuestros domicilios hasta ver qué pasaba» (233).

c) VER (subordinada sustantiva, sin preposición) $+A$. Encuentro tres casos: en uno ver es aposición; en otro, atributo; y en el tercero, objeto directo. En los dos primeros la interrogativa modal expresa "evalución apreciativa» del enunciado; a ello contribuye el sentido afirmativo de ver, pero, también, el interrogativo-exclamativo cómo y otros elementos del contexto (repeticiones, anacolutos):

«Esa borrachera de naturaleza, ver cómo, cómo... allí se vive y se muere de una forma fantástica» (221).

«Mi asombro era en este mismo laboratorio, donde ahora estamos hablando, ver cómo mi maestro, después de un animalito, un ave, recuerdo precisamente un cernícalo, haberle extraído la piel, hecha una armadura, puesto todo aquello, yo lo veía con una facilidad...» $(216)^{23}$.

${ }^{23}$ En este ejemplo el valor de «evaluación apreciativa» está dado también, y principalmente, por asombro, sujeto de la oración de que es atributo la interrogativa modal. Este caso se relaciona, pues, con los estudiados en III.3. 
En el tercer caso, ver, implica negociación («decidi... ver», luego "no lo había visto todavía') y, aunque el interrogativo es cómo, el significado de la proposición es 'evaluación lógica' del enunciado:

«decidí marcharme allá y también ver cómo era capaz de bandeármelas otro poco» (11).

d) VIENDO + A. Hallo sólo dos casos, con el significado de «evaluación apreciativa»; en el segundo se observan alteración del orden de palabras y repeticiones ya analizadas:

«que dé una clase a la semana una serie de, de escritos a máquina viendo cómo se ficha un libro» (309).

«estaba disfrutando muchísimo viendo a los... a los paracaidistas cómo... cómo se tiraban» $(121)^{24}$.

\subsubsection{Perifrasis con VER $+\mathrm{A}$}

Encuentro tres perifrasis con ver que rigen interrogativa modal: ir a ver (nueve casos, entre interrogativas parciales y totales), hay que ver (cuatro casos de interrogativas parciales) y la perifrasis modal poder ver (un caso de interrogativa total). En suma, 14 casos: nueve de parciales y cinco de totales.

Ejemplos de ir a ver:

«pues voy a ver qué pasa» (344).

"Vamos a ver de qué podríamos hablar más» (382).

«Veremos a ver si es interesante» (372).

Con esta perifrasis, en dos casos, se altera el orden de palabras mediante el conocido procedimiento de anticipar elementos de la proposición subor-

Los editores no acentúan estos cómos. 
dinada. En ambos casos el significado de la interrogativa modal parcial parece combinar la "evaluación lógica» y la "evaluación apreciativa» del enunciado. Claro que los interrogativos son el adverbio cómo y el adjetivo cuánto:

«vamos a ver... cuatro hijos, cinco hijos, un marido y una mujer cómo se pueden defender...»(175-76).

«vamos a ver el año que viene cuánta natalidad hay» (176).

Ejemplos de hay que ver:

«Hay que tratarles un poco más y ver por qué es eso» (90).

"porque hay que ver qué cantidad de teatros y qué cantidad de de...» (270).

Se dan los consabidos casos de alteración del orden de palabras:

«y esto es lo que hay que ver cómo se consigue» (175).

«y hay que ver la gente con qué interés sigue, con qué pasión se entusiasma» (224).

En estos ejemplos se ve muy bien que el significado de la palabra interrogativa es un eficaz instrumento - aunque no el único- para expresar la «evaluación apreciativa»; así, el qué adjetivo, con significado «calificativo" e incluso "determinativo" 25 qué interés, qué pasión, qué cantidad.

Finalmente, con poder ver sólo hallo:

«yo tampoco me creo que se pueda ver ya si tienen pecado original o no tienen pecado original» $(50)$.

${ }^{25}$ Cf. B. MALER, Synonymes romans de l'interrogatif "qualis», Estocolmo 1949. 
2.2.4. VER en forma personal $+\mathrm{A}$

Es la variante menos frecuente: seis casos (cinco de interrogativas parciales y uno de total). La parcial está encabezada siempre por cómo y significa "evaluación apreciativa» del enunciado:

«Vemos a nuestro alrededor cómo todos los valores clásicos... se vienen abajo» (169).

"Yo veía cómo aquello iba tomando vida» (216).

«Tú ya verás cómo si te echas novio, el día de mañana, no come de nada y cuando te casas come» (123).

En un caso la interrogativa modal depende de una interrogativa directa:

«lo ves... lo ves cómo no podían ser los marcianos?» (59).

El único caso de interrogativa modal total lleva subjuntivo; éste expresa la duda, y refuerza el significado de "evaluación lógica» del enundiado (cf. 2.1.1.3.):

«ya veré si... midiendo mis esfuerzos desde ahora pueda llegar a... concluir todas en junio" (28).

Un caso especial, que puede interpretarse como mezcla de parataxis e hipotaxis (igual que los vistos en 2.2.1.), lo constituye:

«No veas, qué bochorno!» (405). 
2.2.5. Distribución de la interrogativa modal dependiente de VER

\begin{tabular}{|c|c|c|c|c|c|c|c|}
\hline \multirow{2}{*}{$\begin{array}{l}\text { Tipo de } \\
\text { Encuesta }\end{array}$} & \multicolumn{2}{|c|}{ Sexo } & \multicolumn{4}{|c|}{ Generaciones } & \multirow{2}{*}{ Total } \\
\hline & $\mathrm{V}$ & $\mathrm{H}$ & 1. & 2." & 3." & 4." & \\
\hline $\mathrm{D}$ & 17 & 19 & 8 & 7 & 8 & 13 & 36 \\
\hline E & 5 & 12 & 15 & 2 & - & - & 17 \\
\hline S & 2 & 12 & 14 & - & - & - & 14 \\
\hline TOTAL & 24 & 43 & 37 & 9 & 8 & 13 & 67 \\
\hline
\end{tabular}

2.2.6. Oraciones de relativo con valor de interrogativas modales dependientes de VER

Sólo encuentro cinco casos, distribuidos en todas las variantes que presenta la interrogativa modal, menos en la formada por A VER en construcción independiente (cf. 2.2.). En una sola ocasión aparece por (con valor final), en vez de para, lo que no se daba en las interrogativas modales. Por lo demás, la forma del relativo es siempre lo que:

«¿Empezamos así una cosa, a ver lo que nos sale?» (400).

«... por ver lo que representan» (77).

«Pues ya verás tú lo que me pasó a mí con Preu» (324).

«te colocas detrás de un sitio donde no veas muy bien lo que están haciendo" (136). 
La distribución de estos cinco casos es la siguiente:

\begin{tabular}{|c|c|c|c|c|c|c|c|}
\hline \multirow{2}{*}{$\begin{array}{l}\text { Tipo de } \\
\text { Encuesta }\end{array}$} & \multicolumn{2}{|c|}{ Sexo } & \multicolumn{4}{|c|}{ Generaciones } & \multirow{2}{*}{ Total } \\
\hline & $\mathrm{V}$ & $\mathrm{H}$ & 1." & $2 .{ }^{*}$ & $3 .^{a}$ & 4." & \\
\hline D & - & 2 & 1 & 1 & - & - & 2 \\
\hline $\mathbf{E}$ & 1 & 1 & 1 & 1 & - & - & 2 \\
\hline $\mathbf{S}$ & - & 1 & 1 & - & - & - & 1 \\
\hline TOTAL & 1 & 4 & 3 & 2 & - & - & 5 \\
\hline
\end{tabular}

2.3. Proposiciones interrogativas modales dependientes de otros verbos de entendimiento y percepción

Encuentro los siguientes verbos y locuciones verbales que tienen esos significados o los implican: acordarse (de), adivinar, aprender, averiguar, comprender, conocer, chocar ( = 'causar extrañeza o enfado', lo que implica 'percibir'), darse cuenta de, decidir, depender de, enterarse (de), fijarse (en), imaginarse, juzgar, mirar, recordar, sacar (= 'averiguar').

No todos aparecen con la misma frecuencia: los que más se usan son acordarse (de) y fijarse (con seis casos cada uno); comprender, darse cuenta y enterarse ofrecen dos casos cada uno, y el resto sólo uno.

Únicamente fijarse (en), darse cuenta de y enterarse (de) se documentan rigiendo interrogativas parciales y totales; el resto sólo se halla con interrogativas parciales, que, lógicamente, son mucho más numerosas que las totales.

En la gran mayoría de los casos (en 29 de 35), la interrogativa modal es objeto directo o complemento preposicional del verbo que la introduce:

«no se puede dar uno cuenta bien de, de cómo es la cocina por aquí» (164). 
«me enteraría de una vez ya de cómo son» (51).

«No me acuerdo qué historia era» (338).

«tienes que acordarte de quiénes estaban» (445).

«no me acuerdo ahora cómo se llama» (248).

«No recuerdo qué temas, vamos sobre qué habló» (196).

«y puedo comprender cuándo una música es buena» (168).

«enseguida adivino quién no es madrileño» (178).

«no puedo juzgar de cuál es el... o sea, el modo de pensar y el nivel de estas personas» (38).

«y a mí me gustaria sacarle..., realmente, qué contactos ha tenido" (57).

depende de cómo te lo tomes» (351).

tienen que darse cuenta si valen o no valen» (24).

También, la mayoría de las veces el valor de la proposición es «evaluación lógica». Claro que, en estos casos, el verbo suele estar en construcción negativa o que implica negación. Cuando está en construcción afirmativa, la proposición puede expresar «evaluación apreciativa»:

«ya conoces cuáles son» (268).

Pero, como hemos visto en otros esquemas y variantes, este valor más bien parece un sentido textual que un significado de lengua. A veces, una 
misma proposición puede expresar «evaluación lógica y apreciativa» al mismo tiempo:

«Pero tú crees que se fija en cómo dice Soljenitsin el argumento?» $(297)^{26}$.

El que toda la oración compleja sea una interrogativa directa no es argumento decisivo para que la interrogativa modal signifique, al mismo tiempo, "evaluación lógica y apreciativa» del enunciado, aunque puede ser un factor que influya, en algunos casos, para que la interrogativa directa pierda "sentido inquisitivo" y gane "sentido expresivo", según vimos (cf. 2.1.1.1.b).). Pero en los siguientes casos me parece que está claro el sentido de "evaluación lógica» (y no "apreciativa») de la proposición, aun siendo la oración compleja una interrogativa directa:

«Has mirado tú la... cuándo hemos empezado?» (390).

«Y ¿tú te has enterado si no habiendo cogido la Literatura francesa de tercero se puede coger la de cuarto y la de quinto? (388).

\subsubsection{Exclamativas indirectas en el plano sintagmático}

Con respecto a lo que acabo de exponer, conviene no confundir la proposición interrogativa modal que tiene el sentido de «evaluación apreciativa" del enunciado («ya conoces cuáles son») con otras que expresan la modalidad exclamativa de la enunciación, a las cuales podemos denominar "exclamativas indirectas en el plano sintagmático», en correspondencia con las «interrogativas indirectas en el plano sintagmático» (cf. II.3.).

Repárese en los siguientes ejemplos, en los que aparecen fijarse y mirar en imperativo:

«fijate qué reacción tuvo fulanito» (138).

«iFíjate tú dónde nos quedamos!» (430).

«fijate qué casualidad» (442).

«mira qué bien» (325).

${ }^{26}$ Lo que se lee en el texto de la transcripción es: «iPero tú crees que la fija en cómo dice, etcétera?», lectura errónea a juzgar por el contexto; el error puede ser, desde luego, del propio informante. 
Hasta con la conjunción si de la interrogativa total se emplea esta construcción:

«Pues fijate si he conocido gente, mucha» (273).

En todas estas oraciones el significado de la interrogativa modal -a veces reducida a un solo elemento, sin verbo: "qué casualidad», "qué bien»- se aproxima al de la exclamación directa, si es que no se identifica con él. Esto ocurre incluso en el último ejemplo, el cual tiene una gran importancia teórica, puesto que se ha dicho - y con razón- que las «exclamativas indirectas" no admiten la construcción subordinada con si: *Es extraño (lamentable, sorprendente...) si la trata bien o mal ${ }^{27}$. Pero lo que en nuestro ejemplo hay es una subordinada con si con claro valor exclamativo. No cabe hablar de «exclamativas directas» para definir formalmente las cinco oraciones que comienzan con «fijate» y con "mira». Ni siquiera existe la posibilidad de interpretarlas como producto ambiguo de un cruce de parataxis e hipotaxis, pues no se produce pausa entre el imperativo y el interrogativo-exclamativo o la conjución si. $Y$, sin embargo, ninguna de estas oraciones expresa modalidad del enunciado («evaluación apreciativa»), sino modalidad exclamativa de la enunciación. Es decir, son «exclamativas indirectas en el plano sintagmático» y se corresponden con las «interrogativas indirectas en el plano sintagmático» del tipo dime qué te pasa. Los imperativos fijate y mira son sustitutos sintagmáticos del morfema de entonación exclamativa, lo mismo que lo es dime del morfema de entonación interrogativa. $Y$, como a ellos se subordina una proposición sustantiva interrogativa, ésta no es interrogativa modal, sino exclamativa indirecta en un caso e interrogativa indirecta en otro.

Hay que distinguir, pues, la proposición interrogativa modal con valor de "evaluación apreciativa» del enunciado (a la que se le llama también, con no mucha propiedad, "exclamativa indirecta») de la proposición exclamativa indirecta en el plano sintagmático. Sólo la primera, la modal, no admite la subordinada con si; la segunda sí la admite, en cambio: el ejemplo del habla de Madrid no deja lugar a dudas.

Pero, cuando fijarse y mirar no están en imperativo, la proposición que rigen es una interrogativa modal, con valor de «evaluación lógica» o «evaluación apreciativa» (o de ambas a la vez) del enunciado, según hemos visto en ejemplos del apartado anterior: ¿Has mirado tú... cuándo hemos empezado?, ¿Pero tú crees que se fija en cómo dice Soljenitsin el argumento?

${ }^{27}$ I. BosQue, art. cit., p. 24. 


\subsection{2. ' Construcciones especiales}

Sólo encuentro seis casos en que la interrogativa modal no es objeto directo ni complemento preposicional del verbo de 'entendimiento y percepción'. En tres de ellos es aposición de un sustantivo o pronombre neutro, que son los verdaderos objetos directos del verbo principal:

«La verdad es que yo aprendí COSAS INTERESANTES.

De cómo la poesía está en cualquier cosa» (221).

«yo no LO comprendo, por qué las patatas me gustaron tanto» (264).

¿Tú te imaginas ESTO, qué felicidad?» (332).

En realidad, cada uno de estos tres casos manifiesta su propia peculiaridad; pero en los tres hay un denominador común: entre el verbo principal y el interrogativo se produce una pausa fonológica mayor o menor, consecuencia de la interposición del objeto directo (aunque el pronombre lo del segundo ejemplo exige normativamente la anteposición al verbo). Como resultado de ello, la interrogativa modal adquiere una cierta independencia tonal que, naturalmente, tiene repercusiones en su significado. Lo que, por otra parte, hace ambiguas estas oraciones. (No perdamos de vista que estamos analizando enunciados orales, posteriormente transcritos.) Así, en la primera oración, la interrogativa puede interpretarse, o bien como aposición de "cosas interesantes», o bien como complemento circunstancial (de materia de que se trata) del verbo; en este último supuesto se puede objetar la existencia de pausa larga - un punto en la escritura-, pero tal objección no tiene fuerza en la lengua hablada, en la que la pausa puede estar exigida por varios motivos (expresividad, detenimiento para pensar y ordenar lo que se está diciendo, incluso distracción momentảnea, etc.).

La segunda oración es también ambigua. La pausa y la concomitante independencia tonal de la interrogativa hacen que ésta pueda interpretarse como una oración interrogativa directa, aununciada catafóricamente por el «lo", objeto directo de "comprendo". Esta interpretación es muy verosímil si se observa el contexto lingüístico del enunciado que analizamos:

«por qué?, ipor qué será esto?, ipsss!, yo no lo comprendo, por qué las patatas me gustaron tanto». 
Nótese que el pronombre «lo» también puede referirse anafóricamente a la inequivoca oración interrogativa directa que precede. Por lo demás, este ejemplo es importante teóricamente, porque documenta el orgien paratáctico de las proposiciones interrogativas indirectas y modales (cf. 2.2.1. y n. 20).

En fin, el tercer ejemplo también es ambiguo, aunque, en esta ocasión, su contexto lingüístico no nos aclara cuál es el referente de "esto»: puede ser la proposición -reducida a sintagma nominal: "qué felicidad»-, $\mathrm{y}$, en este caso, vale interpretar que se trata de una aposición del objeto directo de "te imaginas"; pero el pronombre "esto" puede ser también anafórico y referirse a algo de lo dicho antes, y, en este supuesto, la proposición que analizamos sería una variante, coloquial y expresiva (con alteración del orden de palabras, con elipsis del verbo copulativo), de un modelo más normal, del tipo ¡qué felicidad es esto! Sea como fuere, la independencia tonal, también en este caso, acerca la proposición interrogativa modal a una oración exclamativa directa o a una exclamativa indirecta en el plano sintagmático. Como en otros casos ya analizados, el que todo el enunciado vaya marcado por el morfema de entonación interrogativa no invalida la explicación propuesta, antes bien creemos que la corrobora.

En otras tres ocasiones, la interrogativa modal desempeña la función sintáctica de sujeto o la de aposición del sujeto. Ello ocurre, en dos casos, porque en la construcción del período se introduce el giro de realce expresivo con es:

«Hay una cosa que no entiendo, y ES cómo un señor... aunque haya estudiado Filosofia y Letras, puede ser..., por ejemplo, yo pueda dar, cuando termine la carrera, Latín» (308).

«A mí ahora LO QUE más me choca de todo ES la..., la liberbad de expresión que tiene toda la gente joven; cómo hablan, tan crudamente, tan duramente...» (252).

En este segundo ejemplo la interrogativa modal es aposición del sujeto («la libertad de expresión...»); y sería igualmente sujeto de chocar, intransitivo, si el hablante no hubiese empleado la construcción lo que... es...

Finalmente, en un único caso, la interrogativa modal, aposición del sujeto, no está relacionada con ningún verbo de 'entendimiento y percepción' (aunque no se puede descartar la presuposición de alguna de estas notas, sea en el contexto o en la situación):

«lo peor es el empiece, cómo empezamos» (405). 
2.3.3. Distribución de las interrogativas modales dependientes de verbos de 'entendimiento y percepción'

\begin{tabular}{|l|ccc|cccc|c|}
\hline \multirow{2}{*}{$\begin{array}{l}\text { Tipo de } \\
\text { Encuesta }\end{array}$} & \multicolumn{2}{|c|}{ Sexo } & \multicolumn{4}{|c|}{ Generaciones } & \multirow{2}{*}{ Total } \\
\cline { 2 - 7 } & V & H & $10^{2}$ & $2 .^{2}$ & $3 .^{2}$ & $4 .^{2}$ & \\
\hline D & 7 & 14 & 4 & 2 & 5 & 10 & 21 \\
\hline E & 3 & 7 & 7 & 3 & - & - & 10 \\
\hline S & - & 4 & 4 & - & - & - & 4 \\
\hline TOTAL & 10 & 25 & 15 & 5 & 5 & 10 & 35 \\
\hline
\end{tabular}

2.3.4. Oraciones de relativo con valor de interrogativas modales dependientes de verbos de 'entendimiento y percepción'

Hay únicamente siete casos, todos con el relativo lo que. La oración de relativo depende de algunos de los verbos enumerados en 2.3.: darse cuenta, enterarse, fijarse, imaginarse y mirar; además, aparece el verbo sentir, que no encontrábamos con las interrogativas modales. La oración de relativo es siempre objeto directo o complemento preposicional:

«se da cuenta de lo que es la medicina» (134).

«sin enterarme de lo que me estaba diciendo» (113).

«ni se puede imaginar lo que será la sociedad civilizada dentro de diez o de quince años» (169).

«pero ahora siente usted lo que es español» (178). 
Particular interés tienen los siguientes ejemplos, que responden al esquema de la «exclamativa indirecta en el plano sintagmático» (cf. 2.3.1.):

«pero fijate lo que está diciendo la radio» (59).

«Pero fijate tú lo que son ocho años...» (274).

«Pero mira lo que me pasó» (436).

No creo que el significado oracional sea idéntico en fijate lo que está diciendo la radio y fijate qué reacción tuvo, en mira lo que me pasó y mira qué bien. En esta construcción, la proposición interrogativa significa la modalidad exclamativa de la enunciación (en el plano sintagmático); en cambio, la oración de relativo significa la modalidad del enunciado como uevaluación apreciativa» del mismo. El elemento diferenciador está en el interrogativo-exclamativo, y en la entonación y en el acento inherentes. Ello es claro en estos ejemplos, puesto que el imperativo («fijate», "mira») es el mismo para las interrogativas y para las oraciones de relativo. Así, estos ejemplos ponen de manifiesto que el principal rasgo distintivo de las interrogativas (indirectas y modales) es el interrogativo que las encabeza, o la conjunción si, en el caso de las interrogativas totales ${ }^{28}$.

La distribución de estos siete casos es la siguiente:

\begin{tabular}{|l|cc|cccc|c|}
\hline \multirow{2}{*}{$\begin{array}{l}\text { Tipo de } \\
\text { Encuesta }\end{array}$} & \multicolumn{2}{|c|}{ Sexo } & \multicolumn{3}{|c|}{ Generaciones } & \multirow{2}{*}{ Total } \\
\cline { 2 - 7 } & V & H & $1 .^{*}$ & $2 .^{*}$ & $3 .^{*}$ & $4 .^{*}$ & \\
\hline D & 2 & 4 & 1 & 2 & 2 & 1 & 6 \\
\hline E & - & - & - & - & - & - & - \\
\hline S & 1 & - & 1 & - & - & - & 1 \\
\hline TOTAL & 3 & 4 & 2 & 2 & 2 & 1 & 7 \\
\hline
\end{tabular}

${ }^{28} \mathrm{Para} / \mathrm{lo}$ que $/=/$ qué/, cf. E. Alarcos LloraCH, Estudios de gramática funcional del español, Madrid 1982, 3.' ed. pp. 266-267. Y BELLo, Gramática, p. 373 y la nota 138 de Cuervo (pp. 505-506). Pero quien ve muy bien la diferencia significativa entre lo que y qué es KENISTON: qué expresa una incertidumbre actual - dice-, mientras que lo que ofrece un aspecto de definición y certeza en virtud del elemento demostrativo que contiene: ésa es la diferencia entre le preguntaremos qué sabe de eso / lo que sabe de eso (The Syntax..., pp. 150-151). 
3. Interrogativas modales dependientes de sustantivo, adjetivo y preposición

Los 15 casos agrupados bajo este epígrafe constituyen el quinto esquema oracional de la proposición interrogativa, inventariado en el habla culta de Madrid (cf. I.3.). Pero, en realidad, se trata de una extensión de los esquemas tercero y cuarto: la interrogativa no depende de un verbo o locución verbal, sino de un sustantivo, un adjetivo o de la preposición según; ahora bien, en todos los casos los rasgos semánticos de «acto de comunicación» (esquema tercero) o "acto de entendimiento o percepción" (esquema cuarto) se hallan presentes, de un modo explícito o implícito. En todos los casos la interrogativa es parcial, y no encuentro en este esquema oraciones de relativo con valor de interrogativas modales.

La interrogativa modal es complemento de un sustantivo; éste puede significar o implicar "acto de habla", como anécdota y anecdotario, o bien "acto de entendimiento o percepción", como problema, punto de vista, idea y sensación. Lo más frecuente es que sea la preposición de el índice de dependencia sintáctica y de determinación semántica de la interrogativa modal con respecto al sustantivo:

«de anécdota de cómo llegan los ejemplares está el oso de Asturias» (220).

«EJ anecdotario del museo de cómo han llegado los ejemplares es muy interesante» (219-220).

Pero en una ocasión aparece la preposición sobre:

«vamos a buscar ideas sobre qué podemos hacer» (400). 
En otro caso la interrogativa modal parece ser más un complemento de la oración en que se encuentra el sustantivo que del sustantivo mismo, aunque la determinación semántica que ejerce sobre él es evidente (nótese, incluso, la disyuntiva, propia de las interrogativas totales más que de las parciales):

«tienes un gran problema en quién te lo riega o no» (122).

A veces, el hablante vacila entre complementar el sustantivo con una sustantiva enunciativa o con una sustantiva interrogativa modal, y se decide por ésta; el que del ejemplo que sigue es producto de esa vacilación y nada tiene que ver con el mismo que enunciativo de las interrogativas indirectas (cf. II.1.3.), como demuestra la pausa:

«desde el punto de vista de QUE, cómo una mujer evoluciona...» (66).

En fin, no está ausente de este esquema la alteración del orden de palabras, consistente en anticipar algún elemento de la oración subordinada:

«la sensación... de las personas cómo van vestidas...» (153).

Los adjetivos interesado, contento y esclavizado también se complementan con interrogativas modales. No hay mucha duda acerca de la presencia del rasgo "acto de entendimiento o percepción» en los dos primeros; tampoco en el tercero, pues está empleado en la acepción figurada que el DRAE reconoce a esclavizar ('tener a uno muy sujeto e intensamente ocupado'):

«Estoy interesado en qué podrá ser esto» (332).

«hay que estar un poco esclavizado de cómo va la gente» (31). 
En una ocasión el hablante suprime la preposición que debía unir la interrogativa modal con el adjetivo:

«estoy contenta cómo tengo encauzada la vida» (84).

Encuentro seis casos de interrogativas modales dependientes de la preposición según, la cual, pese a su carácter de "palabra gramatical", posee un significado relacionable con un "acto de entendimiento o percepción"; en efecto, el DRAE define ese significado así: 'conforme o con arreglo a'. Por otra parte, las interrogativas modales dependientes de según se singularizan morfosintáctica y sociolingüísticamente.

Por lo que hace a lo primero, son proposiciones reducidas a un sintagma nominal, que es sujeto, objeto directo o complemento; los otros elementos oracionales se eliden o son los de la oración principal. Ello quiere decir que, en los seis casos, la interrogativa modal se identifica con el interrogativo qué seguido de un sustantivo:

«A mí lo que más... según qué películas» (374).

«a mí me sale muchas veces he compr, o sea, según, según con qué participios» (404).

«No, pero según qué cosas» (404).

En dos casos, la preposición que indica la función del interrogativo dentro de la interrogativa modal se antepone a según:

«pero a según qué hora una chica... una chica sola no puede andar...» (377).

«en según qué aspectos es fundamental» (382).

Por según a qué hora y según en qué aspectos, respectivamente. 
La singularidad sociolingüística consiste en que las interrogativas modales dependientes de según se hallan, exclusivamente, en enunciados de informantes hembras, menores de 25 años (de la 1." generación), en los estilos correspondientes a las encuestas "espontáneas» (E) y «secretas» (S).

Finalmente, la distribución de los 15 casos del esquema que acabo de analizar se ve en el cuadro:

\begin{tabular}{|l|cc|cccc|c|}
\hline \multirow{2}{*}{$\begin{array}{l}\text { Tipo de } \\
\text { Encuesta }\end{array}$} & \multicolumn{2}{|c|}{ Sexo } & \multicolumn{4}{|c|}{ Generaciones } & \multirow{2}{*}{ Total } \\
\cline { 2 - 7 } & V & H & $1 .^{2}$ & $2 .^{2}$ & $3 .^{\mathrm{a}}$ & $4 .^{2}$ & \\
\hline D & 4 & 3 & 3 & 1 & 1 & 2 & 7 \\
\hline E & 1 & 3 & 4 & - & - & - & 4 \\
\hline S & - & 4 & 4 & - & - & - & 4 \\
\hline TOTAL & 5 & 10 & 11 & 1 & 1 & 2 & 15 \\
\hline
\end{tabular}

\section{Interrogativas modales dependientes de NO HABER Y NO TENER}

Este sexto y último esquema que encontramos en el habla de Madrid está documentado en latín y en español desde orígenes (como casi todos los otros). En la lengua medieval es el esquema que más se emplea en los textos no literarios, sobre todo en fueros y documentos. Hacemos estas observaciones previas para subrayar el contraste que significa su escasa presencia en la lengua culta que se habla en Madrid hoy. 
El esquema se caracteriza por varias notas: haber y tener se construyen negativamente y no significan «acto de comunicación» ni «acto de entendimiento y percepción") (como tampoco tienen este significado hallar, encontrar y otros verbos que se usan también en este esquema, aunque no aparecen en las encuestas despojadas); la interrogativa es siempre parcial (únicamente encuentro «por qué» como forma del interrogativo) y objeto directo, y lleva el verbo en infinitivo, ya que su sujeto es el mismo del verbo principal ${ }^{29}$. Como he dicho, el esquema está muy poco representado en el corpus; sólo aparecen seis casos, dos con no haber y cuatro con no tener:

«No hay por qué seguir siempre a nuestros padres» (89).

«no tiene por qué haber una Lógica del sí y del no» (53).

La distribución es ésta:

\begin{tabular}{|l|ccc|cccc|c|}
\hline \multirow{2}{*}{$\begin{array}{l}\text { Tipo de } \\
\text { Encuesta }\end{array}$} & \multicolumn{2}{|c|}{ Sexo } & \multicolumn{3}{|c|}{ Generaciones } & \multirow{2}{*}{ Total } \\
\cline { 2 - 7 } & V & H & $1 .^{\mathrm{a}}$ & $2 .^{\mathrm{a}}$ & $3 .^{\mathrm{a}}$ & $4 .^{\mathrm{a}}$ & \\
\hline $\mathrm{D}$ & 3 & 2 & 1 & 1 & 2 & 1 & 5 \\
\hline E & - & - & - & - & - & - & - \\
\hline S & - & 1 & 1 & - & - & - & 1 \\
\hline TOTAL & 3 & 3 & 2 & 1 & 2 & 1 & 6 \\
\hline
\end{tabular}

${ }^{29}$ Dejo fuera de este esquema las relativas con subjuntivo, del tipo «no hay quien pueda", que ya no tienen valor alguno de interrogativas modales, aunque muchas de ellas sí lo tenían en español medieval. 
Como en el anterior esquema, tampoco en este se documentan oraciones de relativo con valor de interrogativas modales.

\section{Conclusiones}

1. De lo expuesto en las páginas anteriores se desprende la existencia de dos clases paradigmáticas de proposiciones interrogativas: las interrogativas indirectas (que significan la modalidad de la enunciación) y las interrogativas modales (que significan la modalidad, lógica o apreciativa, del enunciado). En el plano sintagmático hay un esquema de interrogativa indirecta (DIME + A), documentado desde orígenes del español y presente en la muestra que hemos analizado; en esta muestra hemos encontrado un esquema similar de exclamativa indirecta en el plano sintagmático (cf. III.2.3.1.): FiJATE o MIRA + A. También en el plano sintagmático algunas oraciones de relativo tienen el valor de interrogativa indirecta o de interrogativa modal, según el verbo, locución verbal o palabra de que dependan.

2. Atendiendo ahora exclusivamente a las proposiciones interrogativas, indirectas y modales, y a los esquemas oracionales en que aparecen (cf.I.3.), debemos señalar que hemos encontrado un total de 345 casos y que la frecuencia, en porcentajes, de cada uno de los esquemas es la siguiente:

a) Interrogativas indirectas:

1) PREGUNTAR (y sus sinónimos decir y pensar) + A ... 6,37\%

2) DIME (y construcciones equivalentes) $+\mathrm{A} \ldots \ldots \ldots \ldots \ldots \ldots . . .1,16 \%$

b) Interrogativas modales:

3) DECIR (o verbo de 'comunicación') + A …............. 3,48\%

4) SABER, VER (o verbo de 'entendimiento y percepción') $+\mathrm{A}$ $82,90 \%$

5) Sustantivo, adjetivo o preposición + A ……............ 4,34\%

6) NO HABER, NO TENER + A .............................. $1,74 \%$ 
2.1. Las interrogativas indirectas ocupan sólo el 7,53 por 100 del total. Significan, como hemos dicho, la modalidad de la enunciación, que es modalidad interrogativa la mayoría de las veces, pero que también puede ser modalidad exclamativa (cf.II.2.). A ese 7,53 por 100 corresponden 26 casos en total, pues prescindimos del único caso de "pregunta indirecta libre» (cf.II.4.) por tratarse de una estructura que va más allá del marco oracional. Considerando únicamente la totalidad de los 26 casos, se puede establecer la frecuencia de las interrogativas indirectas en los siguientes porcentajes:

PREGUNTAR, PREGUNTA, DECIR Y PENSAR + A ... $84,61 \%$
DIME + A $\ldots \ldots \ldots \ldots+\ldots . . .15,38 \%$

Hay que señalar que en el primero de estos dos esquemas el que enunciativo aparece en un 40,9 por 100 de los casos, en construcciones del tipo «nos ha preguntado QUE qué pasaba» (cf.II.1.1.).

Lo normal en la construcción de los esquemas oracionales que contienen una interrogativa indirecta o una interrogativa modal es que éstas sigan inmediatamente al verbo o palabra que las rige, $o$, en otro caso, que ocupen la posición que les corresponde en el período (sujeto, aposición, etc.). En las interrogativas indirectas encontramos dos tipos de construcciones que se apartan de esta norma gramatical: aquellas en las que se produce alteración del orden de palabras y aquellas otras en que se produce ambigüedad. $\mathrm{La}$ alteración del orden de palabras adopta, principalmente, las siguientes modalidades: atracción de elementos de la subordinada a la principal, giros de realce expresivo (sobre todo, «lo que...es...)), interposición de elementos parentéticos entre el verbo o locución introductores de la interrogativa y ésta, supresión de elementos de relación (preposiciones, por ejemplo), etc. La ambigüedad está ocasionada por la interferencia de la construcción hipotáctica y de la paratáctica: por ejemplo, «dime qué dijo» y «dime, qué dijo".

La frecuencia de las interrogativas indirectas que se apartan de la norma gramatical descrita es la siguiente:

PREGUNTAR + A $15,38 \%$

DIME + A $7,69 \%$ TOTAL $23,07 \%$ 
La distribución porcentual de estos casos "no normativos», según el sexo, la edad y el estilo de los informantes, queda reflejada en el siguiente cuadro:

\begin{tabular}{|c|c|c|c|c|c|c|c|}
\hline \multirow{2}{*}{$\begin{array}{l}\text { Tipo de } \\
\text { Encuesta }\end{array}$} & \multicolumn{2}{|c|}{ Sexo } & \multicolumn{4}{|c|}{ Generaciones } & \multirow{2}{*}{ Total } \\
\hline & V & $\mathbf{H}$ & $1 .^{a}$ & $2 .^{a}$ & $3 .^{2}$ & 4. ${ }^{\mathrm{a}}$ & \\
\hline D & 16,66 & 33,33 & 16,66 & 16,66 & - & 16,66 & 50 \\
\hline $\mathrm{E}$ & 33,33 & 16,66 & 50 & - & - & 一 & 50 \\
\hline $\mathbf{S}$ & - & - & - & - & - & - & - \\
\hline TOTAL & 50 & 50 & 66,66 & 16,66 & - & 16,66 & 100 \\
\hline
\end{tabular}

Si se compara este cuadro con los consignados en II.1.4., II.2. y II.3 (y no perdemos de vista el que describe la muestra en I.4.), resulta fácil establecer algunas observaciones:

a) siendo el número de «hembras» mayor que el de "varones», se produce una igualación de unas y otros en el uso de las construcciones que se apartan de la norma gramatical, lo que quiere decir que los casos de alteración del orden de palabras y de ambigüedad se dan más en la lengua de los hombres que en la de las mujeres;

b) las interrogativas indirectas se usan menos en las encuestas «secretas» que en las «espontáneas» (a pesar de que el número de unas y otras es el mismo): acaso por eso no aparecen construcciones divergentes de la norma en $\mathrm{S}$;

c) tampoco los informates de la tercera generación usan construcciones divergentes, si bien hay que tener en cuenta que es la generación menos representada en la muestra. 
2.2. Las interrogativas modales son mayoritarias, con respecto a las interrogativas indirectas, en una proporción del 92,46 por 100 . Con respecto al total de 319 casos, la frecuencia de sus esquemas es la siguiente:

DECIR (u otro verbo de 'comunicación') + A $3,76 \%$

SABER, VER (u otro verbo de 'entendimiento o percepción') + A $89,65 \%$

Sustantivo, adjetivo o preposición $+\mathrm{A}$ $4,70 \%$

NO HABER, NO TENER + A $1,88 \%$

A la vista de estos datos, queda destacado el empleo frecuentísimo en la lengua hablada del esquema SABER, VER u otro verbo + A, con 286 casos. Esto quiere decir, en primer lugar, que este esquema es el más representativo de la interrogativa modal, lo mismo que PREGUNTAR + A es el más representativo de la interrogativa indirecta. En segundo lugar, conviene poner de relieve el mayor uso de saber y de ver que el de cualquier otro verbo de «entendimiento y percepción»: con relación a los 286 casos la frecuencia de estos verbos es la siguiente:

saber $64,33 \%$

ver $23,42 \%$

Aún hay que llamar la atención sobre la mayor frecuencia de NO SABER + A que la de SABER + A, y la de A VER + A en construcción independiente que la de cualquiera otra construcción de ver. $Y$, finalmente, dentro de este mismo esquema, debe señalarse la aparición de la variante FIJATE (o MIRA) + A, una «exclamativa indirecta en el plano sintagmático" (cf.III.2.3.1), variante que no habiamos encontrado en el español medieval y cuya frecuencia absoluta es similar a la de DIME + A (la «interrogativa indirecta en el plano sintagmático»): un 1,45 por 100. (DI$\mathbf{M E}+\mathbf{A}$ representa un 1,16 por 100: of.2.) Esta exclamativa indirecta es 
importante desde un punto de vista teórico: expresa la modalidad exclamativa de la enunciación - y no la evaluación apreciativa del enunciado, como otras mal llamadas "exclamativas indirectas», del tipo "ya sé cuál es»-, y por eso puede admitir la subordinación con si, cosa que no ocurre en estas otras que podríamos llamar «exclamativas modales».

Con respecto a los otros esquemas (y en comparación con lo inventariado en el español medieval), hay que anotar, en la lengua hablada en Madrid, la disminución de DECIR + A y de NO HABER, NO TENER + $\mathbf{A}$, correspondiente al aumento de sustantivo, adjetivo o preposición $+\mathbf{A}$.

Las construcciones que se apartan de la norma gramatical adoptan, en las interrogativas modales, las dos peculiaridades observadas en las interrogativas indirectas: alteración del orden de palabras y ambigüedad (cf.2.1.); no consideramos alteraciones del orden de palabras las interrogativas inconclusas, del tipo "no sé qué», "a ver si...» (cf.III.2.1.1.4. y III.2.2.1.). Pero a esas dos modalidades divergentes de la norma hay que añadir una más en las interrogativas modales: la que consiste en la vacilación (sus motivos son muy varios en la lengua hablada), de modo que el hablante comienza a construir una subordinada sustantiva enunciativa, la interrupe y construye una sustantiva interrogativa, o comienza una interrogativa total y la sustituye por una parcial, o sugiere una oración de relativo con valor de interrogativa modal y luego se decide por esta última, como en «les des... pelos y señales... de todo LO QUE... de qué le ha pasado al libro" (127).

La frecuencia de las construcciones no normativas, por esquemas, es la siguiente:

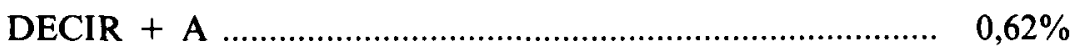

SABER, VER, etc ............................................... $9,09 \%$

Sust., adj., prep …................................................ $\quad 1,56 \%$

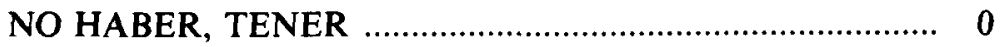

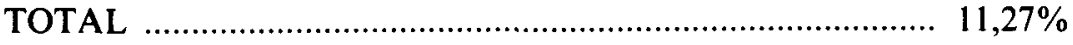

La distribución, en porcentajes, según sexo, edad y estilo, es la que se recoge en el cuadro siguiente: 


\begin{tabular}{|c|c|c|c|c|c|c|c|}
\hline \multirow{2}{*}{$\begin{array}{l}\text { Tipo de } \\
\text { Encuesta }\end{array}$} & \multicolumn{2}{|c|}{ Sexo } & \multicolumn{4}{|c|}{ Generaciones } & \multirow{2}{*}{ Tota } \\
\hline & V & $\mathbf{H}$ & 1." & $2 .^{\circ}$ & 3." & 4." & \\
\hline D & 25 & 33,33 & 16,66 & 8,33 & 13,88 & 19,44 & 58,33 \\
\hline $\mathrm{E}$ & - & 16,66 & 13,88 & 2,77 & - & - & 16,66 \\
\hline $\mathbf{S}$ & 2,77 & 22,22 & 25 & - & - & 一 & 25 \\
\hline TOTAL & 27,77 & 72,22 & 55,55 & 11,11 & 13,88 & 19,44 & 99,99 \\
\hline
\end{tabular}

Haciendo las oportunas comparaciones con los cuadros de los diversos apartados de III., podemos anotar las siguientes observaciones:

a) los esquemas y variantes de la interrogativa modal se presentan más fijos y estables —en suma, más ajustados a la norma gramatical-que los de la interrogativa indirecta: los casos que se apartan de la norma representan sólo un 11,27 por 100 , frente al 23,07 por 100 de las mismas construcciones en la interrogativa indirecta (cf.2.1.), y aún hay que considerar que la interrogativa modal es mucho más frecuente que la indirecta;

b) en los varones, en los informantes de la tercera generación y en los estilos correspondientes a las encuentas $\mathbf{D}$ y $\mathbf{S}$ se percibe un uso de las construcciones no normativas ligeramente mayor que el de las hembras, los informantes de las otras generaciones y el estilo correspondiente a $\mathbf{E}$.

3. La muestra deja ver claramente que la oración de relativo con valor de interrogativa indirecta y modal es muy poco frecuente: representa únicamente el 11,99 por 100 (47 casos, frente a los 345 de interrogativas indirectas y modales). La frecuencia relativa de esta oración es ésta: 
a) Interrogativas indirectas:

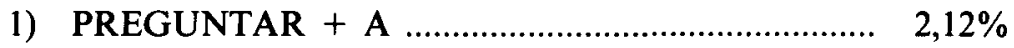

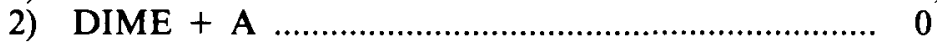

b) Interrogativas modales:

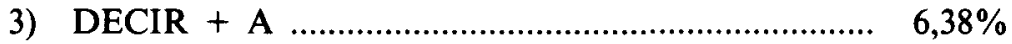

4) SABER, VER, otro verbo + A ..................... 91,49\%

5) Sust., adj. o prepos. + A ................................... 0

6) NO HABER, NO TENER + A ........................ 0

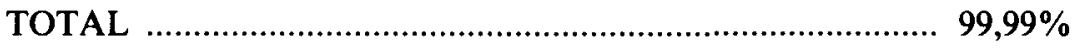

Nótese que la oración de relativo aparece sólo con los esquemas 1), 3) y 4); que encontramos un solo caso con valor de interrogativa indirecta (cf.II.1.5.) y que en el 91,49 por 100 de los casos se usa el relativo sin antecedente en la forma neutra «lo que».

Lógicamente, sólo en las que tienen valor de interrogativas modales se encuentran construcciones que se apartan de la norma gramatical; estas construcciones responden a los modelos ya contemplados: alteración del orden de palabras, ambigüedad y vacilación; su frecuencia, por esquemas, es:

DECIR + A $2,17 \%$

SABER, VER, etc. + A $8,69 \%$ TOTAL $10,86 \%$

La distribución en porcentajes de este 10,86 por 100 se muestra en el cuadro: 


\begin{tabular}{|l|cc|cccc|c|}
\hline \multirow{2}{*}{$\begin{array}{l}\text { Tipo de } \\
\text { Encuesta }\end{array}$} & \multicolumn{2}{|c|}{ Sexo } & \multicolumn{3}{|c|}{ Generaciones } & \multirow{2}{*}{ Total } \\
\cline { 2 - 6 } & V & H & $1 .^{a}$ & $2 .^{a}$ & $3 .^{a}$ & $4 .^{a}$ & \\
\hline D & - & 60 & - & 40 & 20 & - & 60 \\
\hline E & - & 40 & 20 & 20 & - & - & 40 \\
\hline S & - & - & - & - & - & - & - \\
\hline TOTAL & -100 & 20 & 60 & 20 & - & 100 \\
\hline
\end{tabular}

Podemos concluir que las oraciones de relativo con valor de interrogativas modales que se apartan de la norma gramatical se hallan preferentemente en las hembras, en los informantes de la segunda y la tercera generación y en el estilo correspondiente a $\mathbf{D}$.

4. Por último, señalaré algunas cuestiones que no he cuantificado -pero que he ido apuntando a lo largo de este trabajo-, y que podrían ser objeto de otro estudio. Por ejemplo, en general son más numerosas las interrogativas parciales que las totales (tanto en la interrogativa indirecta como en la modal); la función sintáctica desempeñada por la proposición interrogativa es mayoritariamente la de objeto directo; y, en fin, sería interesante comparar las listas de verbos y palabras introductoras de la interrogativa que traen las gramáticas y los estudios monográficos - por ejemplo, el de I. Bosque y el de J. Martínez Marín- con los que realmente aparecen en la muestra estudiada, lo mismo que establecer la frecuencia de los distintos interrogativos. 